British \& Irish Botany 1(2): 128-166, 2019

\title{
Achene morphology of British and Irish mayweeds and chamomiles: implications for taxonomy and identification
}

\author{
Chris A. Skilbeck*, Iris Lynch, Maggie Ellenby, Mark A. Spencer
}

Department of Life Sciences, Natural History Museum, London, SW7.

*Corresponding author: Chris A. Skilbeck, email: skilbeckus@yahoo.com

This pdf constitutes the Version of Record published on $21^{\text {st }}$ May 2019

\begin{abstract}
Whilst determining the mayweed and chamomile specimens in the Natural History Museum's British \& Irish Herbarium we decided to produce a photographic guide and key to assist in the determination of these plants using achene morphology. Because of our observations, and in line with North American treatments, we propose recognising Matricaria discoidea subsp. discoidea and M. discoidea subsp. occidentalis as separate species. We also discuss possible introgression from Tripleurospermum maritimum subsp. phaeocephalum in northern parts of Birtain and Ireland, the implications for the taxonomy of Anthemis/Cota and Chamaemelum and the usefulness of achene glands in determination of specimens. Finally we consider the problems that may arise when using immature achenes and herbarium specimens for determination and we discuss the usefulness of being aware of changes in colour and form that occur during development, particularly as many collected specimens lacked ripe capitula.
\end{abstract}

\section{Keywords: Anthemis, Cota; Chamaemelum; Matricaria; Tripleurospermum;}

\section{Introduction}

Mayweeds and chamomiles can be a difficult group to determine to species and subspecies level and on a global scale their taxonomy is still challenging (Oberprieler, 1998, 2002; Lo Presti et al., 2010). Although there are differences in habit and leaf morphology, there is also tremendous variation within each species. Also, some species are superficially similar and may grow together in the same habitat (Kay, 1971a, 1971b, 1972). Although the number of native species in Britain and Ireland is more restricted than on the continent (Bremer \& Humphries, 1993; Tutin et al., 1976), determination is complicated by the increasing frequency of some non-native species. Identification can be further complicated by hybridisation. Reliable determination may depend upon microscopical examination of achene and receptacle scale characteristics. However, published descriptions may be incomplete or conflicting in detail, or they may be text only and lacking in visual aids. Furthermore, there are complications due to level of maturity of the achenes and differences between fresh and preserved specimens. To 
address these issues, while curating the Natural History Museum's (BM herbarium) collection of British and Irish Chamaeme/um Mill., Anthemis L., X Anthepleurospermum Rothm., Matricaria L. and Tripleurospermum Sch. Bip. specimens, we did a photographic study of achene morphology, supplemented with detailed descriptions of morphology based on the literature and our own observations. We have also supplemented our data by collecting fresh material in various stages of development for selected species. To facilitate determination of British and Irish mayweeds and chamomiles in the field and herbarium, a key based upon achene morphology has been produced.

\section{Achene morphology within the Anthemidae}

Plants of the Asteraceae are characterised by possessing one or more compound inflorescences, or capitula, in which each capitulum consists of one or more whorls of bracts (phyllaries) and a cluster of true flowers, or florets, grouped together on a receptacle. Each floret can produce a single seeded, dry and indehiscent fruit in which the pericarp closely fits the seed without adhering to it. This fruit has been variously described as an achene or a cypsela (Fig. 1). However, some authors prefer the term 'cypsela' as defined as a one-seeded dehiscent fruit derived from a bicarpellate ovary with a single chamber, restricting 'achene' to one-seeded dehiscent fruit derived from a monocarpellate ovary also with only a single chamber (e.g. Ranunculus). In this paper, we will follow Stace (2019) and refer to the fruit of Asteraceae as achenes.

The faces of an achene are often labeled as abaxial and adaxial or ventral and dorsal (Fig. 1). These terms can be used differently and can cause confusion. The side making the smallest angle to the inflorescence axis is usually referred to as the adaxial surface or ventral side of the achene. In leaves and achenes alike, this is the upper surface when the shoot axis is upright and vertical. What many people may think of as the 'back' of a leaf or the undersurface is defined as the dorsal side of the achene or the abaxial surface. We shall use the term adaxial for the 'upper' or ventral surface and abaxial as the 'lower' or dorsal surface.

The distal end (achene apex) of the mature achene bears a tissue outgrowth called the stylopodium ('foot of the style', Fig. 1) at the position the style was attached when in flower. This term is variously defined as a platform of tissue (generally parenchyma derived from a meristem) supporting the style, or the style base plus a surrounding ring of nectiferous tissue. We have adopted the broadest and most literal definition of 'stylopodium' as the base of the styles and associated structures which remain attached to the achene. This is similar to the definition given by Jana \& Mukherjee (2015) of the stylopodium as the 'modified persistent style base'. Associated with this there may be a ring of tissue derived from the base of the corolla tube.

The distal end frequently also bears a full or partial ring or pappus of hairs or scales, which in Mayweeds and Chamomiles is either absent or reduced to a paper corona or corolla or an apical rim (Fig. 1). This pappus or rim is noticeably asymmetric in Anthemis, being reduced or absent on the abaxial side and longer adaxially. 
The proximal end (the base) bears tissue known as the carpopodium ('foot of the carpel', Fig. 1) where the achene was attached to the receptacle during development and may be derived from receptacular tissue. The achene may also possess clearly defined ribs (costae) and/or weaker ribs (striae). The clearly defined ribs (costae) appear to have differing developmental origins, true ribs have an interior consisting of an expansion of new cells, formed from a meristem, whereas pseudo-ribs may simply protrude from underlying structures such as oil canals (Briquet, 1916). In this paper we have chosen to use the term 'rib' to describe both costa and pseudo-rib, and 'weak rib' to describe stria. Usually, in Chamaemelum, there are two lateral weak ribs and a single adaxial weak rib, each of which is accompanied by a vascular strand (Bremer \& Humphries, 1993). The ribs may bear wart-like protuberances (tuberculae) as in Anthemis cotula.

The achene may also possess one or more glands of several types. The ovaries of many Asteraceae possess ovarian glandular hairs. For example, in Matricaria chamomilla the ovarian glandular hairs consist of two columns of cells (biseriate trichomes): two basal cells, two peduncle cells and three pairs of secretory cells. Secretions accumulate beneath the cuticle (in the subcuticular chamber) at the head of the gland. Rupture of the cuticle releases the secretion (Andreucci et al., 2008). The same study reported similar glands on the stems, leaves, bracts and corolla as well as the ovary. Histochemical analysis revealed that those on the bracts, corollas and ovaries were rich in lipid secretions in addition to essential oils, sesquiterpene lactones and pectic-like substances (Andreucci et al., 2008).

Other gland types may be present, such as 'resin ducts', if elongated, and 'resin sacs', if more sac-like in form. Resin sacs (Fig. 1) may also be called 'oil glands'. Strictly speaking, a 'resin' is a highly viscous liquid or solid, otherwise the term 'oil' is perhaps more appropriate. Resin ducts may be internal and only visible upon sectioning the achene (Briquet, 1916) or they may be visible if they are very close to the surface. These glands and ducts contain essential oils (Andreucci et al., 2008).

Finally, some achenes possess mucilage secreting or mucilaginous cells. For example, the achenes of Chamaemelum (Bremer \& Humphries, 1993; Briquet, 1916) and M. chamomilla (Inceer, 2011) have longitudinal rows of mucilage-secreting or myxogenic cells on the pericarp surface. These secrete 'slime' which expands when hydrated for 1 to 5 minutes, to form a gel envelope (Inceer, 2011). Absorption of water by the gel is thought to aid germination in osmotically stressful and saline habitats. For example, the mucilage aids dew absorption which has been shown to assist DNA repair in Artemisia sphaerocephala (Yang et al., 2011). Mucilaginous cells have also been recorded on the ribs of Anthemis arvensis (Briquet, 1916; Oberprieler, 1998) and on the tuberculae of $A$. cotula (Briquet, 1916). It should be noted that the presence, number, size and shape of mucilaginous cells has some taxonomic value, for example in Anthemis (Oberprieler, 1998).

Alongside the achenes on the capitulum, receptacle scales are present in Chamaemelum and Anthemis although they may not necessarily be associated with 
every floret in Anthemis. The shape of the receptacle scales may also be a diagnostic character (Sell\& Murrell, 2006; Stace, 2019).

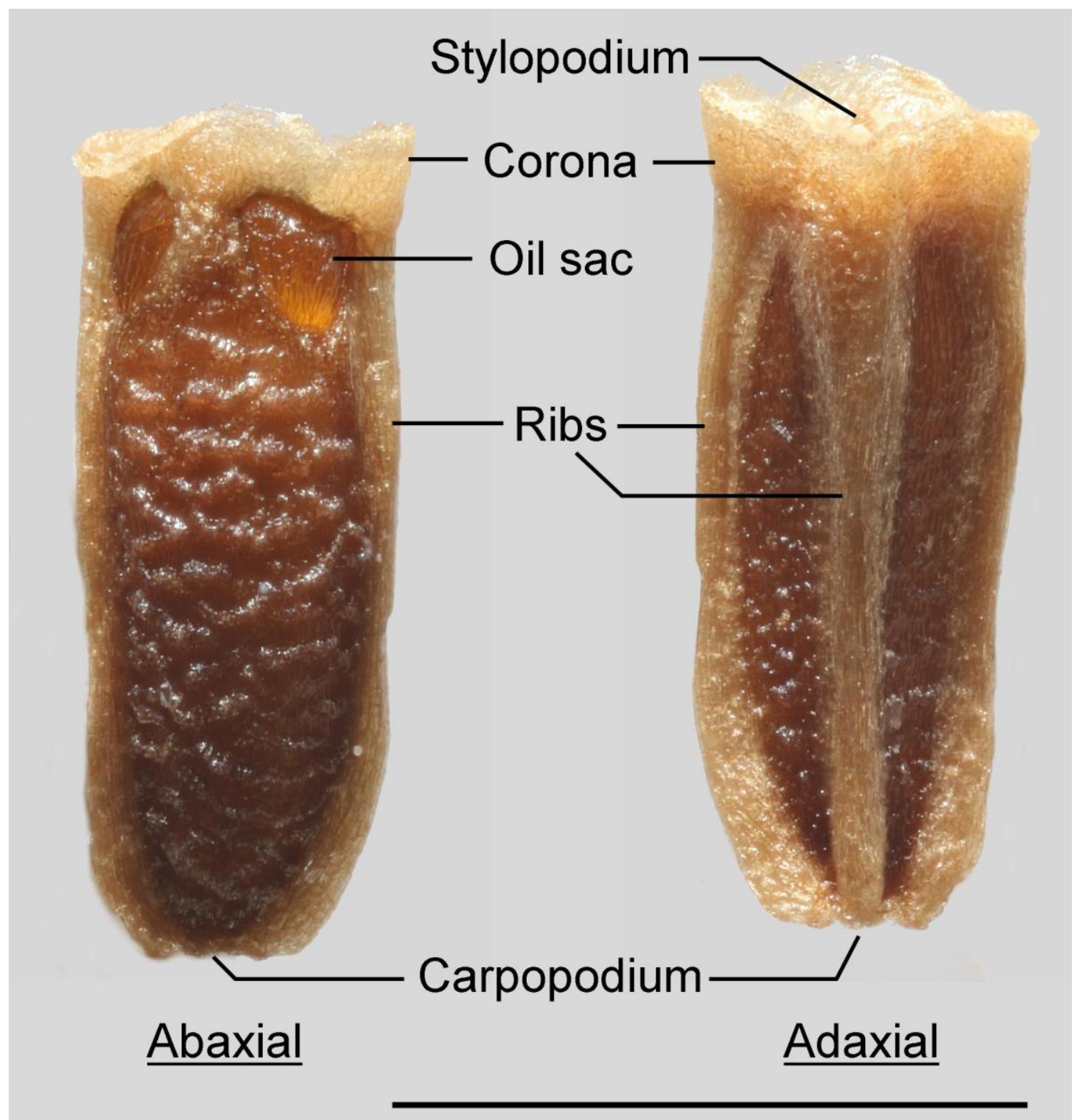

Figure 1. General morphology of the achene of Tripleurospermum inodorum (Scentless Mayweed, v.c. 15); Scale bar = $1 \mathrm{~mm}$.

\section{Taxonomic coverage of this study}

The following taxa treated in Stace (2019) are covered in this study: Chamaemelum nobile (L.) All., Anthemis punctata subsp. cupaniana (Tod. ex Nyman) R. Fern., $A$. arvensis L., A. cotula L., Cota austriaca Jacq., C. tinctoria L., X Anthepleurospermum maleolens (P. Fourn.) Stace, Matricaria chamomilla L., M. discoidea DC., Tripleurospermum maritimum (L.) W.D.J. Koch and T. inodorum (L.) Sch. Bip. All these 
plants are either archaeophytes or neophytes apart from Chamaemelum nobile and Tripleurospermum maritimum which are both considered native (Stace, 2019).

The neophyte Cota tinctoria is a variable species with a wide European distribution (Tutin et al., 1976) and several subspecific taxa are currently recognised; of these, the following have been recorded in Britain and Ireland: $C$. tinctoria subsp. tinctoria, $C$. tinctoria subsp. australis R. Fern., and C. tinctoria subsp. subtinctoria (Dobrocz) Soó and are accepted by Stace (2019). A fourth taxon, A. tinctoria subsp. fussii (Griseb.) Beldie (Sell \& Murrell 2006; Tutin et al., 1976) was not included in this study due to lack of available material. As well as the aforementioned infraspecific taxa, Sell and Murrell (2006) discussed two rare and potentially under-recorded coastal variants of Anthemis arvensis (var. anglica (Spreng.) Syme) and A. cotula (var. vectensis (F.N. Williams) P.D. Sell), these too were included in the study.

The N.E. Asian and western N. American Matricaria discoidea is separated into two taxa in Sell \& Murrell (2006) and Stace (2019): M. discoidea subsp. discoidea and M. discoidea subsp. occidentalis (Greene) P.D. Sell. The latter taxon was originally described by Greene (1886) as Matricaria occidentalis Greene. Later in this paper we will discuss our rationale for recommending that this taxon's specific status be recognised by British and Irish botanists.

The widespread Northern Hemisphere Tripleurospermum maritimum is a variable plant (Sell \& Murrell, 2006; Stace, 2019; Tutin et al., 1976). Stace recognised the following three subspecies within Britain and Ireland: T. maritimum subsp. maritimum, T. maritimum subsp. vinicaule P.D. Sell and T. maritimum subsp. nigriceps P.D. Sell. Subspecies nigriceps appears to be restricted to northern mainland Scotland, Orkney and Shetland although there is a 2010 record from Cumberland (BSBI Database sourced 22/09/2017). This northern taxon has often been confused with the arctic T. maritimum subsp. phaeocephalum (Rupr.) Hämet-Ahti. Hitherto, there have been no grounds for considering subsp. phaeocephalum to be present in Britain or Ireland but later in this paper we consider the possibility of introgression with extant T. maritimum populations in the British Isles. Hybridisation has been widely reported between T. maritimum s.l. and $T$. inodorum (Stace et al., 2015); as yet, there does not appear to be a validly published name for this hybrid.

In Britain and Ireland, there are no known naturally occurring hybrids within Anthemis, however, hybridisation is known to have played an import role in the evolution of the genus (Lo Presti et al., 2010). Interestingly, hybrids between Anthemis and Tripleurospermum are known to occur within our area, although probably extremely rarely (Sell \& Murrell 2006; Stace 2019). As well as X Anthepleurospermum maleolens (Anthemis cotula $\times$ Tripleurospermum inodorum), another intergeneric hybrid, X Anthepleurospermum gruetterianum (Asch.) Rothm (= X Tripleurothemis gruetterana (Asch.) P.D.Sell) ( $A$. arvensis $\times$ T. inodorum) has also been reported (Kay 1971b).

In addition, the following neophyte taxa represented in the British and Irish Herbarium were examined: Chamaemelum mixtum (L.) All., Anthemis ruthenica Bieb., Cota altissima (L.) J. Gay, Tripleurospermum disciforme (C.A. May.) Sch. Bip. and T. 
decipiens (Fisch. \& C.A. May.) Bornm. The following non-native taxa cited by Clement \& Forster (1994) were excluded from this study either because of a lack of relevant material or taxonomic and/or nomenclatural uncertainty: Chamaemelum fuscatum (Brot.) Vasc., Anthemis abrotanifolia (Willd.) Guss., A. hyalina DC., A. leucanthemifolia Boiss. \& Blanche, A. maritima L., A. muricata (DC.)Guss., A. tomentosa L., A. triumfetti (L.) All., A. wiedemanniana Fisch. \& C.A. Mey., Matricaria aurea (Loefl.)Sch.Bip., M. oreades Boiss. (= Matricaria breviradiata (Ledeb.) Rauschert) and Matricaria trichophylla (Boiss.)Boiss. (= Tripleurospermum tenuifolium (Kit.)Freyn ex Freyn). None of these taxa have recent (post 1990), verified records in the BSBI Database (searched 25/09/2017).

\section{Materials and Methods}

Mayweeds and chamomiles in the British and Irish Herbarium at the Natural History Museum were determined using Stace (2010) and updated to Stace (2019) with additional help from the studies by Kay $(1971 a, 1971 b, 1972)$ and the floras of Sell \& Murrell (2006) and Tutin et al. (1976). Where there was insufficient material in the British and Irish Herbarium we referred to materials in the Natural History Museum's General Herbarium (the rest of the world). We also referred to the BSBI Database to check records of occurrence in Britain and Ireland of all taxa.

Identification of mayweeds and chamomiles in Stace (2019) and the other Floras (Sell \& Murrell, 2006; Tutin et al., 1976) is largely based upon perennation, habit, leaf morphology, ligule colour, presence or absence of receptacular scales and achene structure. We undertook detailed examination of achenes as a means of supplementing these characters, some of which are not readily observable in herbarium specimens. Examination of the specimens typically necessitated the removal of a small number of achenes from a capitulum, except in specimens where capitula had already been removed and stored or were readily visible on the mounted specimens. Determination of specimens was primarily based on achene characters, although other characters, such as receptacle scales, phyllaries, hairiness, plant habit, leaf form and perennation were also used for verification. Selected 'typical' achenes were photographed with a Cannon EOS 750D using a stacking system controlled by Helicon Focus 6.6.1 software (Helicon Soft).

Further observations were also made on fresh materials of Cota austriaca, Matricaria chamomilla, M. discoidea, Tripleurospermum maritimum and T. inodorum to ascertain changes that may have occurred on drying and storage and to help verify the changes the achenes go through during development and maturation, particularly in terms of colour and gland structure.

To verify the likelihood of suspected interspecific hybrids of Tripleurospermum and intergeneric hybrids of Tripleurospermum with Anthemis we compared the collection sites to regions known to possess both parents with the help of Stace's Hybrid Flora of the British Isles (Stace et al., 2015). If a specimen with intermediate habit and leaf characters came from a locality where both parents have been recorded, then it was considered a potential hybrid. For T. inodorum x T. maritimum we also used Kay's semi- 
quantitative scale for achene characters (Kay, 1972): the achenes sampled were scored on oil-sac shape/elongation and rib thickness. On Kay's scale, a score of 1 to 3 for oil sac elongation indicates $T$. inodorum, 4 to 9 T. maritimum and a score of 1-3 for rib thickness indicates $T$. inodorum, 4 to $5 \mathrm{~T}$. maritimum. Where a discrepancy is found between rib thickness and oil sac elongation scores, a hybrid or an introgressed specimen was suspected.

\section{Results}

Descriptions of the key morphological features of the achenes of each species, subspecies and variety examined follow.

\section{Chamaemelum nobile (Chamomile) and Chamaemelum mixtum (Mediterranean Chamomile)}

The ray florets of Chamaemelum are female and sometimes fertile, those of $C$. nobile develop fully and are probably fertile, whereas those of $C$. mixtum developed to varying degrees suggesting variable fertility of the ray florets. The corolla tube of $C$. nobile disc florets have a very distinctive swollen sac at their base. This sac covers the apex of the achene more-or-less symmetrically (Fig. 2a). The receptacle scale partially wraps quite tightly around the achene as well as the lower portion of the corolla tube abaxially (the receptacle scale is sometimes described as canaliculate). This arrangement is similar in C. mixtum, except that in the latter the corolla-tube overlaps the achene very asymmetrically, enclosing almost the entire adaxial side of the achene (Fig. 2b), whereas in $C$. nobile the corolla tube base encloses only the very apex of the achene. This is, in part, a consequence of the position of the stylopodium, which is apical in $C$. nobile (Fig. 2e) and displaced adaxially in C. mixtum (Fig. 2f).

The achenes of both $C$. nobile and $C$. mixtum are obovoid, abaxially-adaxially compressed and weakly ribbed on the adaxial face (Fig. 2c) which is sometimes slightly flatter than the more convex abaxial face (Fig. 2d). There are two weak lateral ribs and one adaxial. These weak ribs are whitish in colour and were only found on some specimens. It is probable that the ribs only appear at maturity, but in many cases large and apparently well-developed achenes lacked them. In $C$. nobile, the achenes sometimes had 4 to 6 of these weak ribs. This ribbing may be present in both disc and ray achenes. In addition, the achenes of both species have additional very faint longitudinal ridges, which are numerous and the same brownish colour as the achene. These possibly correspond to the longitudinal rows of mucilage-secreting or myxogenic cells reported by Bremer \& Humphries (1993). Glandular trichomes were sometimes visible between the weak ribs as yellow globules (arrows in Fig. 2c). In both species, the pappus is either absent or visible as an inconspicuous apical rim.

\section{Anthemis punctata subsp. cupaniana (Sicilian Chamomile)}

This is also known as the 'Fishguard Chrysanthemum' due to it being naturalised in and around Fishguard in Wales. The achenes are weakly to moderately ribbed and have a pappus corona up to $1 \mathrm{~mm}$ in length. The corona is strongly asymmetric, being longer 

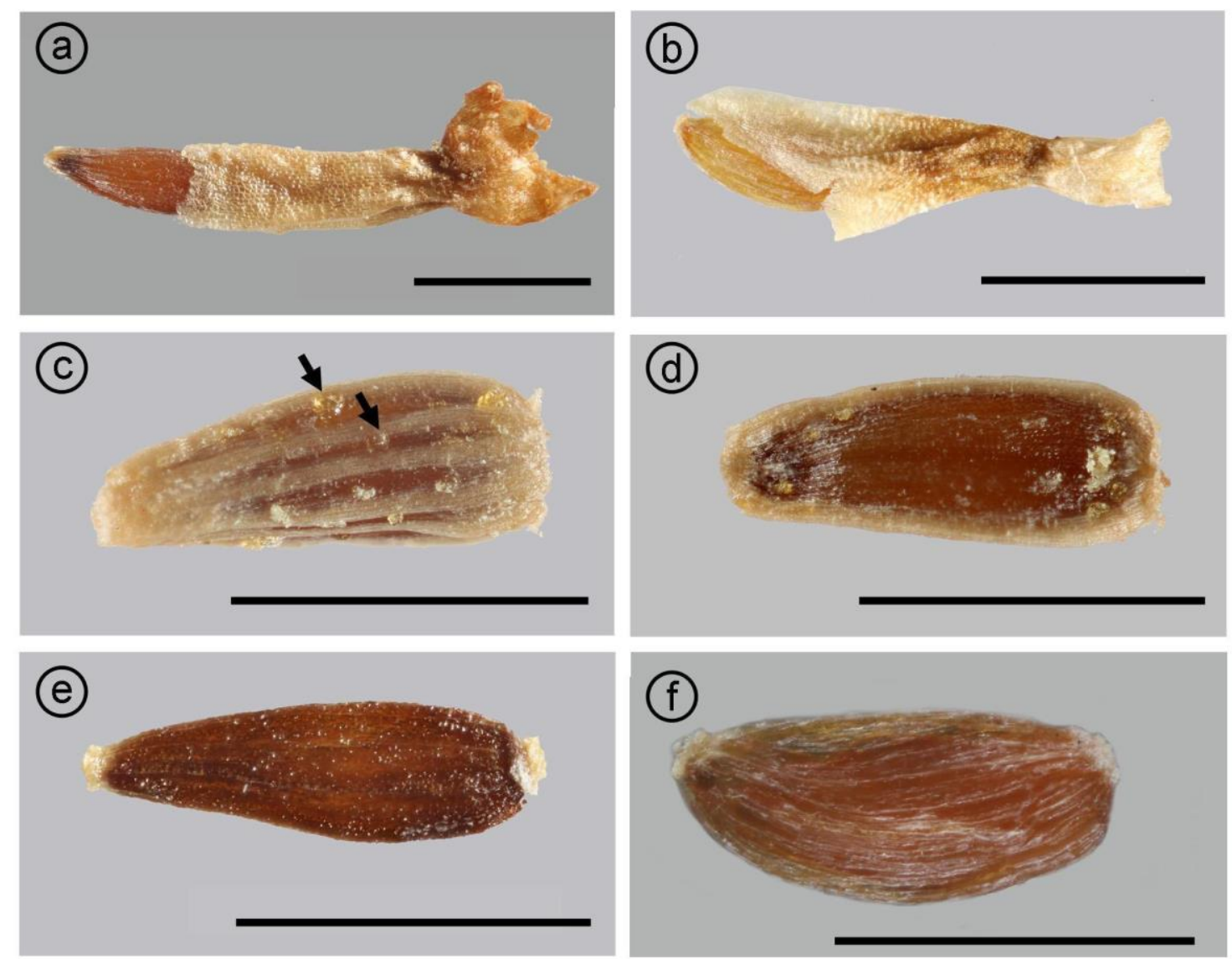

Figure 2. Chamaemelum achenes. Scale bars $=1 \mathrm{~mm}$; the apical or stylopodial end is on the right. a) An immature achene of $C$. nobile (v.c. 1) illustrating the characteristic overlap of the apex of the achene by the base of the corolla, which overlaps the achene equally on all sides. b) An immature achene of $C$. mixtum (v.c. 21) illustrating the characteristic overlap of the apex of the achene by the base of the corolla, which overlaps the achene much more strongly adaxially. $\mathrm{c}$ and d) Achene of $C$. nobile (v.c. 13) in adaxial (c) and abaxial (d) view. Note the weak ribs on the adaxial face (c) and that the achene is characteristically abaxially-adaxially compressed; the glandular trichomes (arrows) in the furrows between the weak ribs. These weak ribs are only apparent in some achenes, particularly the more mature achenes. E and f) An achene of $C$. nobile (e, v.c. 19) compared to an achene of C. mixtum (f, v.c. 21) showing the characteristic alignment of the stylopodium and carpopodium in $C$. nobile which are characteristically offset to one side in $C$. mixtum due to the abaxial-adaxial asymmetry imposed on the achene by the unequal overlap of the corolla base.

on the adaxial side (Figs. 5a, b). The mature achenes have longitudinal rows of elongated whitish cells, which in many specimens appear as rows of white flecks and an overall whitish appearance. The achenes have been described as 'not granulate', whereas those of $A$. punctata subsp. punctata (which occurs in North Africa but has not 
been recorded in Britain and Ireland) have been described as having 'distinctly ribbed and granulate' achenes (Tutin et al., 1976). To understand what 'granulate' refers to in this case, we examined herbarium specimens of subsp. punctata (from North Africa) and subsp. cupaniana (from continental Europe).

The achenes of subsp. punctata lacked the white cells on their pericarp surface, which was instead studded with numerous minute pits. Some specimens also had occasional, incomplete rows of brown longitudinal flecks, resembling those that are more clearly developed in $A$. ruthenica. No clear differences were seen in the strength of ribbing in the few specimens we examined, which varied from weak to moderate in both subspecies.

\section{Anthemis arvensis (Corn Chamomile)}

The disc floret achenes are ovoid to strongly conical in profile and either straight or often noticeably curved, being concave adaxially and convex abaxially. They are typically very tightly packed in the capitulum and it has been observed that they remain on the capitulum for quite some time before being completely shed (Kay, 1971b). There are grooves (sometimes reddish in colour) between the 10 or more moderately strong ribs (Fig. 3a) (Oberprieler (1998) gives the number of ribs as 8 to 11). Ribbing, however, may vary from weakly ribbed where the achenes are almost smooth to very strong. This is a character which can be very variable in the same capitulum. In particular the more peripheral achenes are often larger and more strongly ribbed. The pappus is represented by a short apical rim, which is occasionally incomplete (Fig. 3a). The ray floret achenes are typically full-looking, more triangular in cross-section, moderately to strongly ribbed and with a flatter abaxial (Fig. 3b).

Three herbarium specimens named as $A$. arvensis var. anglica from v.c. 28 (1914), 83 (1880), and H38 (1847) were examined. These specimens had a prostrate habit, as described by Sell \& Murrell (2006), as did specimens from other localities which were not determined as var. anglica, e.g. from v.c. 20, 22 and 83. The achenes from these specimens were within the normal range of variation we saw in $A$. arvensis and hence are indistinguishable. Syme (1866) reported that in cultivation var. anglica was indistinguishable from typical $A$. arvensis. The Natural History Museum's v.c. 83 materials collected from Crookston are the same plants referred to by Syme (1866).

\section{Anthemis cotula (Stinking Chamomile)}

A. cotula typically has 8-11 ribs ornamented with tuberculae (Fig. 3c, d, e) which distinguish the achenes of $A$. cotula from those of $A$. arvensis. Sometimes the tuberculae are very weakly developed (Fig. 3c) and the achene may appear almost smooth or very weakly ridged and hard to distinguish from the weakly-ribbed achenes of $A$. arvensis. Importantly, the achenes of $A$. cotula lack the apical rim (occasionally an incomplete and weak rim may be present) and the apex of the achene then appears rounded and convex. The achenes of $A$. cotula ray florets always appear small, flat and empty-looking or withered in dried specimens. This agrees with Kay's observation that the ray florets are sterile (Kay, 19721a). The two species can be further distinguished 
by differences in the receptacle scales, as noted by Stace (2019). The receptacle scales of $A$. cotula are usually confined to the apical third or two-thirds of the receptacle, very rarely more, they also differ in shape (Stace, 2010).
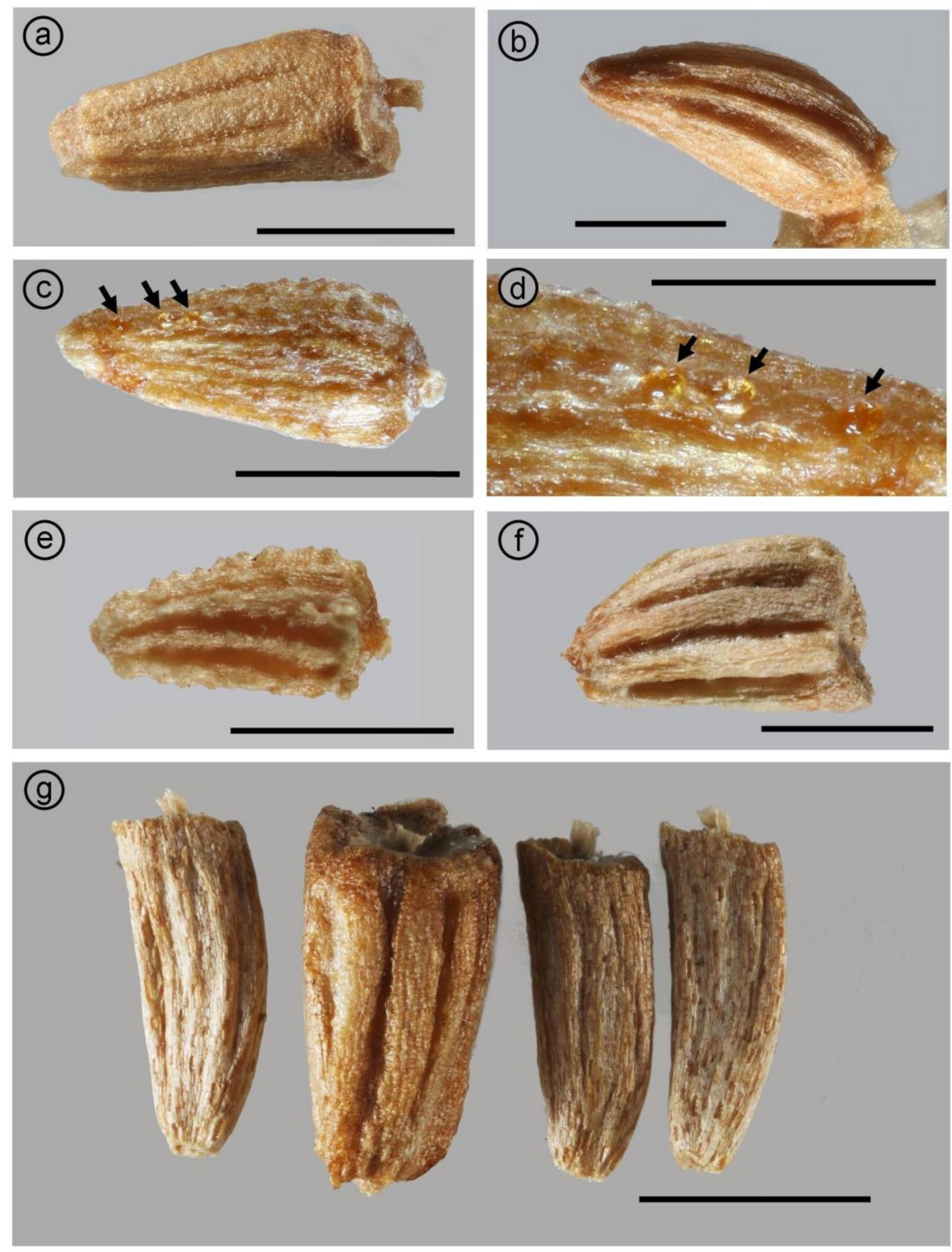
Figure 3. Achenes of Anthemis spp. Scale bars = $1 \mathrm{~mm}$; the apical or stylopodial end is on the right for horizontal achenes, uppermost for vertical achenes. a) Disc achene of $A$, arvensis (v.c. 13) in lateral view. Note the weakly defined ribs, lack of tubercles and the weakly developed pappus rim. b) Ray achene of A. arvensis (v.c. 17) in lateral view, ligule still attached. Note the curvature (abaxial face convex) and the well-developed and prominent ribs. c) Disc achene of A. cotula (v.c. 64) in lateral view. Note that the glandular trichomes present in rows in the furrows between the ribs in many Asteraceae, are still often present in ripe achenes of $A$. cotula and visible as yellow droplets (arrows). Note the absence of a pappus, which is generally either absent or a very weakly developed rim or auricle (asymmetric rim better developed adaxially) in $A$. cotula. This gives the achenes a distinctly rounded apex, in contrast to the flattened apex of $A$. arvensis (a). d) Close-up of the glandular trichomes in (c). e) Achene of $A$ cotula (v.c. 64) illustrating the differing degrees of development of the ribs and the tubercles or protuberances borne along the ribs when compared to (c). These tubercles are a characteristic feature of $A$. cotula. f) Achene of $A$. ruthenica (non-native, this specimen from v.c. 64/65.). Note the broad conical shape and the deep furrows between the distinctive ribs. The furrows have a characteristically different colour and texture to the ribs, being smoother and darker. g) Achenes of A. ruthenica from the same plant as (f) showing the striking dimorphism characteristic of this species: some achenes are slenderer and much less distinctly ribbed, the latter often having longitudinal rows of elongated brown flecks.

An additional observation is that the mature achenes of $A$. cotula very frequently have rows of yellowish oil droplets on the mature achenes of dried herbarium specimens (fig. 3c, d). These droplets occur between the rows of tubercles. According to Oberprieler (1998) most species of Anthemis he studied in West and Central North Africa which had ribbed achenes had sessile biseriate glands in the furrows between the ribs. However, it is not clear to what extent these glands persist in the mature achenes. The retention of these droplets on apparently mature achenes in herbarium specimens was a reliable indicator of $A$. cotula.

Anthemis cotula var. vectensis has been reported from sandy beaches in the Isle of Wight and Somerset and 'should be looked for elsewhere on the south coast' and has a distinctive prostrate habit and fleshy leaves (Sell \& Murrell, 2006). We found a single specimen in the Natural History Museum which possibly fits this description, collected from v.c. 9 (Dorset) in 1912. The stems of this specimen were prostrate and distally ascending as inflorescences. However, the leaves appeared no different from those of $A$. cotula in general and the achenes were typical of $A$. cotula. 
Cota austriaca (Austrian Chamomile, formerly Anthemis austriaca)

This species has only relatively recently (post-2000) become frequent in Britain and Ireland, primarily as a component of so-called 'wild-flower' seed mixes. Due to a lack of suitable material in the British and Irish Herbarium, we examined achenes of $C$. austriaca from the General Herbarium as well as freshly collected material from v.c. 21 (Figs. $4 a, b$ ). The achenes of $C$. austriaca are obovate and adaxially-abaxially compressed (with acute lateral angles) but more-or-less rhomboid and has 2-3 weak ribs (unlike $C$. altissima which has more, see below) on each of the adaxial and abaxial faces. Structures resembling myxogenic cells were lacking (this was also observed by Bhar \& Mukherjee, 2004).

Cota tinctoria (Yellow Chamomile, formerly Anthemis tinctoria)

Flora Europaea describes the achenes of C. tinctoria as 'slightly striate on the faces' and with a very short pappus corona (usually less than one quarter the length of the achene) (Tutin et al., 1976). Three subspecies have been recorded in the wild in Britain and Ireland: subspp. tinctoria, australis R. Fern. and subtinctoria (Dobrocz.) Soó; the fourth, subsp. fussii Griseb. \& Schenk, is only known here as a garden plant (Sell \& Murrell 2006). However, determination to subspecies level proved difficult for the herbarium specimens, particularly as characteristics used by the keys, such as hairiness, seem very variable; perhaps supporting the suggestion that many British and Irish specimens are likely to be horticultural hybrids (Stace, 2010). A combination of characters, including habit, inflexion of the teeth and phyllary characteristics were employed, as noted in Flora Europaea (Tutin et al., 1976). No differences in achene morphology have been reported between the three subspecies and the achenes of all the specimens examined had the same morphology as described in Flora Europaea. Plants possibly referable to subsp. subtinctoria yielded no mature achenes in the samples taken. Those identified as subsp. australis had achenes indistinguishable from those of the more common subspecies. tinctoria (Fig. 4d).

\section{Anthemis ruthenica (Eastern Chamomile)}

There are currently nine separate herbarium specimens, made between 1908 and 1957 determined, as $A$. ruthenica in the British and Irish Herbarium. These were collected from v.c. 17, 19 and 33 from a range of habitats including docklands, flour mills, waste ground and rubbish tips. The achenes of $A$. ruthenica have a flattened adaxial surface and convex abaxial surface. Both abaxial and adaxial surfaces are deeply and strongly ribbed in the largest achenes (Fig. 3f, g). The ribs on the flattened adaxial surface often appear squashed and the furrows between them are less conspicuous, probably due to restricted growth in the crowded capitulum. The pappus rim may possess a short adaxial auricle. The disc achenes appear heteromorphic and can vary considerably in degree of ribbing (Fig. $3 \mathrm{~g}$ ) with larger prominently ribbed achenes sharing the capitulum with small weakly ribbed achenes, the former possibly being more mature. At least some of the achenes (most obviously the weakly ribbed ones) have irregular longitudinal rows of elongated dark flecks contrasted against a whitish pericarp; this 
latter feature was noted by Bhar \& Mukherjee (2004). Our specimens agree well with the achene morphology description given in Flora Europaea (Tutin et al., 1976).

Verloove (2012a) commented that $A$. ruthenica has been seen in Belgium in recent years and is similar to $A$. arvensis and may possibly be under-recorded. There are no recent records from Britain and Ireland (BSBI Database accessed 25/01/2018).
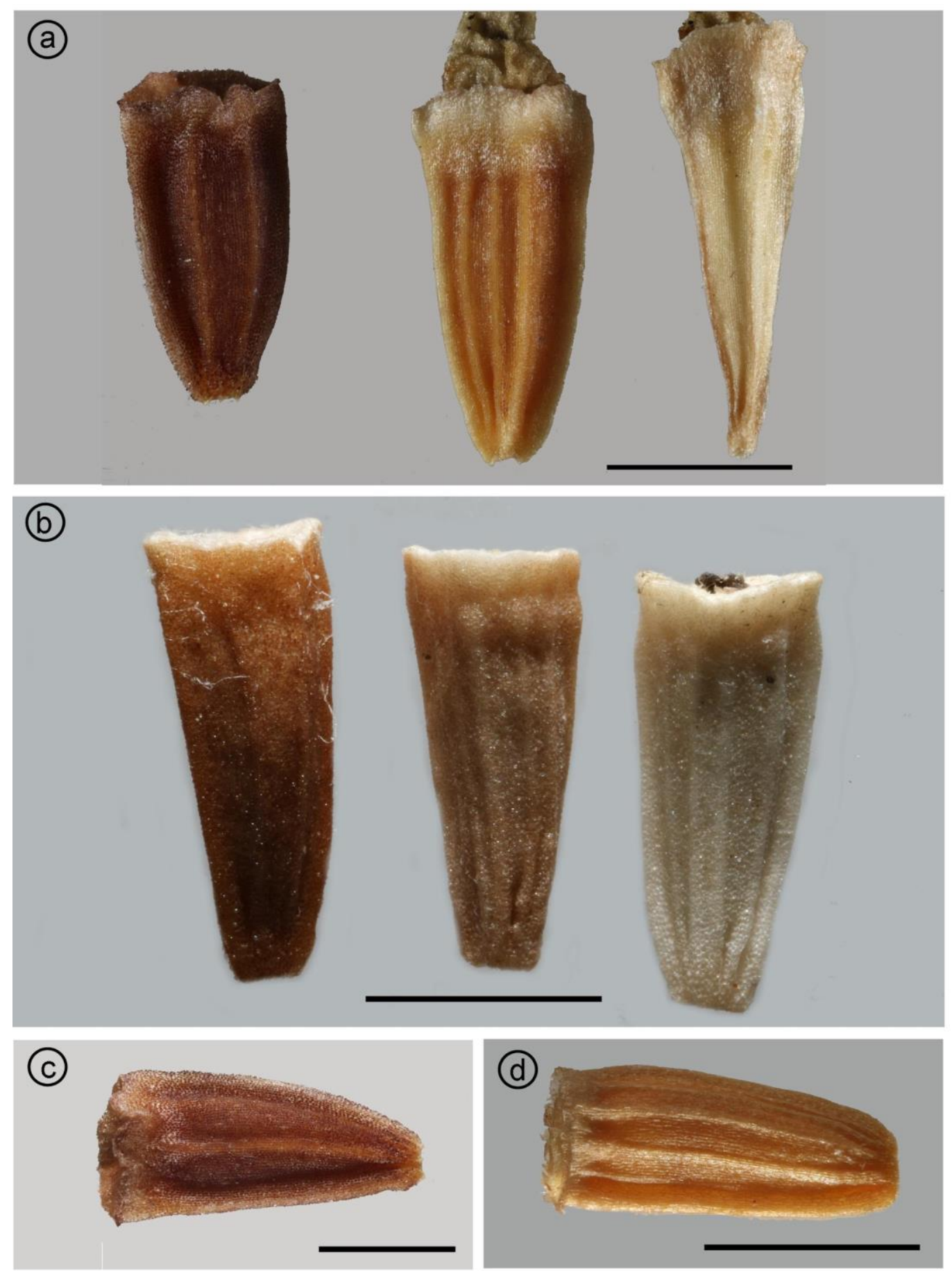
Figure 4. Species of Cota. Scale bars $=1 \mathrm{~mm}$; the apical or stylopodial end is on the left for horizontal achenes, uppermost for vertical achenes. a) Three achenes of $C$. austriaca, from the same plant (v.c.21), showing variation in maturity from most mature (left) to least mature (right). Note that the achenes are characteristically adaxially-abaxially compressed (the rightmost achene is seen in lateral view) with 2-3 ribs on each face. The abaxial and adaxial faces are not easily distinguished. Note that the ribs characteristically converge and merge at the base of the achene. b) Achenes of C. austriaca from the same freshly collected plant as (a) showing the colour changes that result from different stages of maturity. c) Achene of $C$. austriaca. Note that the achene is characteristically adaxially-abaxially compressed with 2-3 ribs on each face. The abaxial and adaxial faces are not easily distinguished. d) Achene of $C$. tinctoria subsp. tinctoria (v.c. 15).

\section{Cota altissima (Southern Chamomile, formerly Anthemis altissima)}

The achenes of $C$. altissima are described by the Flora Europaea (Tutin et al., 1976) as 'obpyramidal-subcompressed, very narrowly winged' and typically with (7-)8 to 10(-11) weak ribs on either side and with a short apical rim or pappus corona. The disc achenes are also described as quadrangular and the ray achenes as triangular. Specimens examined conformed to this description (Fig. 5c), one of which was 'A. austriaca' redetermined as $C$. altissima. The ray achenes have a flattened, but slightly convex, abaxial surface, such that the abaxial angle is weakly developed. There is a real possibility of confusing $C$. altissima with $C$. austriaca which differs in having fewer weak ribs (2-3) but also in the nature of the receptacle scales which have a pointed tip as long as the blade, whereas in C. austriaca the tip is shorter than the blade, often much more so. However, it is likely that some specimens may still cause confusion and both the number of weak ribs on the achene and the receptacle scale form should be considered when carrying out determinations. Examination of the achenes will also distinguish these two species from $A$. punctata subsp. cupaniana; the latter however is a very different looking plant and confusion is unlikely.

\section{$X$ Anthepleurospermum maleolens and $X$ Anthepleurospermum gruetterana}

The hybrid between Anthemis cotula and T. inodorum, X Anthepleurospermum maleolens (P. Fourn.) J.M.H. Shaw, has been reported in Britain (Sell \& Murrell, 2006; Stace, 2019) and has also been produced experimentally (Kay, 1971a). The putative hybrid between Anthemis arvensis and T. inodorum, Anthepleurospermum gruetterana (Asch.) Rothm. (= X Tripleurothemis gruetterana (Asch.) P.D. Sell, see Pliszko \& Heise, 2016) has been grown from achenes collected from Oxford (Kay, 1971b). We identified a single herbarium specimen as possibly an Anthemis $\mathrm{x}$ Tripleurospermum hybrid. This was collected from v.c. 112 (Shetland) in 1919 (Fig. 12e, f). The achenes from this material frequently had 5 or more moderately strong ribs, the exact number often being difficult to count as some of the ribs were often partially formed. They were conical in shape when mature, resembling the achenes of Anthemis arvensis in contour, but had 
as many as 4 oil sacs (absent in $A$. arvensis). However, no receptacle scales were found, whilst it is reported that some specimens of $X$ Anthepleurospermum maleolens have weakly developed receptacular bracts (Kay, 1971a). Some of the achenes also appeared typical of $T$. inodorum. It is possible that this specimen was one of the unusual Tripleurospermum forms (see below) with extra ribs and oil glands, however, the frequency of abnormal achenes, the strength of the additional ribs and the conical form made the achenes of this specimen unlike any other Tripleurospermum found in the BM herbarium. It is also worth noting that the only Anthemis recorded from Shetland, $A$. arvensis, appears to be very rare thus making hybridisation very unlikely (BSBI Database sourced 26/09/2017).
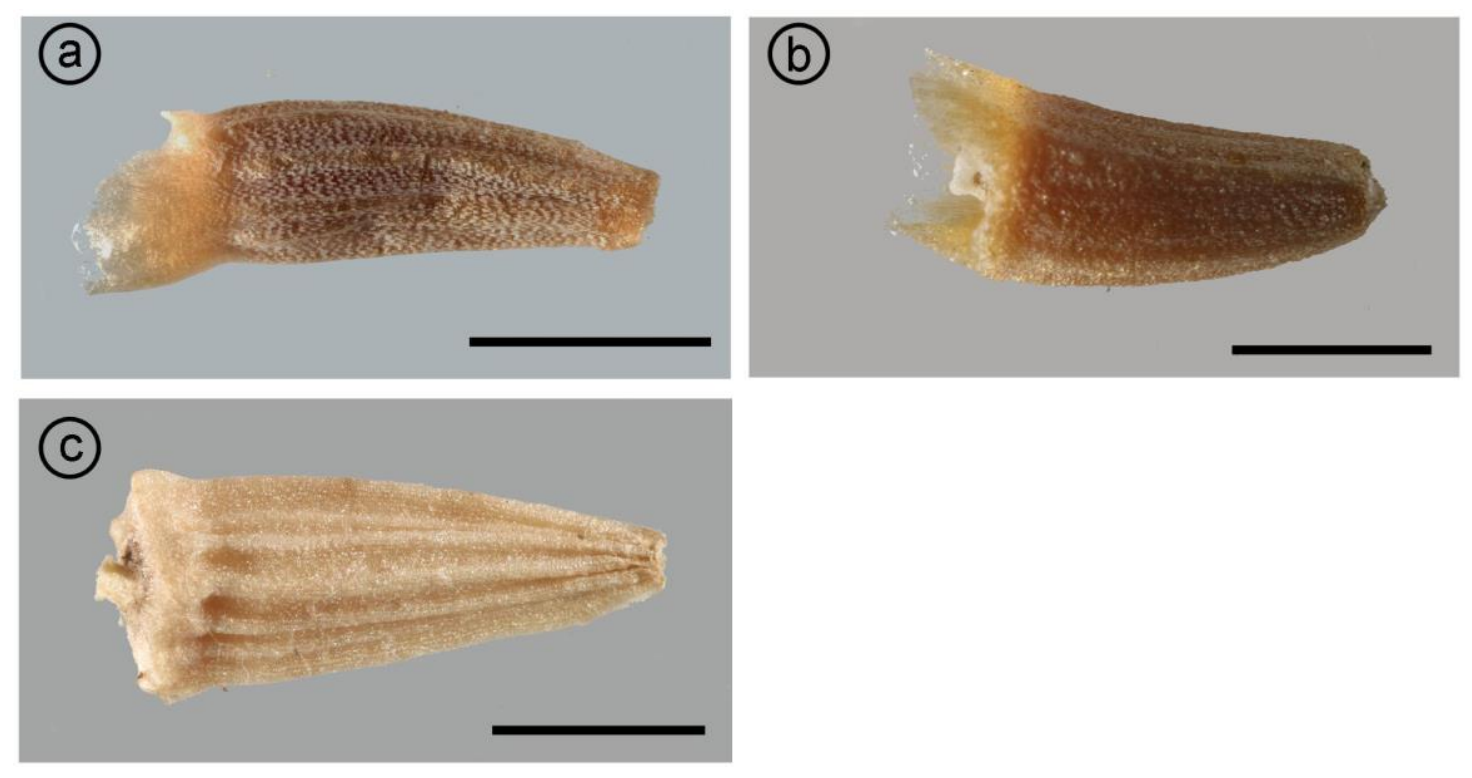

Figure 5. Anthemis and Cota achenes. Scale bars $=1 \mathrm{~mm}$; the apical or stylopodial ends are on the left. $a, b)$ Achenes of $A$, punctata subsp. cupaniana (v.c. 13). Note the typically large pappus, which accentuates the Anthemis genus characteristic of being more highly developed or taller on the adaxial side of the achene. Note the pale or whitish rows of elongated cells in (c) which are apparent in some of the achenes, the degree of this colouring depending on both achene and individual plant. c) Achene of Cota altissima (v.c. 12). Note the characteristically high number (8-10) of weak ribs (which occur on both the adaxial and abaxial faces).

Matricaria discoidea subsp. discoidea (Pineappleweed)

The disc achenes of $M$. discoidea subsp. discoidea are straight to slightly concave adaxially, convex abaxially (Fig. 6c), there are no ray achenes. Usually a pair of (rarely 0 , sometimes 3 or 4 ) brown to red lateral stripes (oil canals/ducts) are visible in herbarium specimens (Fig. 6c, e, f). In fresh material the stripes are initially green in unripe achenes (Fig. 6d), yellowing and turning brown or red in ripe achenes, the full 
redness of the colour may develop several days after dehiscence. This is important when identifying fresh material, since the green stripes contrast less with the translucent pale green achene in immature specimens but are nevertheless visible (Fig. $6 d)$. These stripes are visibly inflated (especially in less mature achenes), and in fresh achenes will release essential oil easily when lightly pierced.

The pappus is reduced to or replaced by a small apical rim (Fig. 6c). The pair of oil canals typically penetrate inside the pappus apically and can be seen as two red spots when the achene is viewed apically (Fig. 6e). In the middle of the pappus is a short polygonal to cylindrical stylopodium. There are usually 4 moderately strong adaxial ribs, the lateral two bearing the oil canals over most of their length, although the medial two may also develop oil canals in cases where 3 or 4 oil canals are visible; usually this is only for part of their length. The extent of canal development is quite variable (Fig. 7e). A prominent ring-shaped rim marks the proximal attachment point (carpopodium) to the receptacle.

Examination of freshly collected 'green' material revealed longitudinal rows of yellow glandular drops located between the adaxial ribs (Fig. 6e) on at least some of the apparently mature achenes. These resemble the glandular trichomes seen in $M$. chamomilla.

\section{Matricaria discoidea subsp. occidentalis (Valley Mayweed)}

Only five specimens of this taxon were identified in the British and Irish Herbarium. The two lateral oil canals extend into a lateral pair of ear-like projections of the pappus (Fig. 7a). This character was distinctive in all specimens and clearly separated them from subsp. discoidea without ambiguity. As in subsp. discoidea, the oil canals can be seen to clearly penetrate inside the pappus (Fig. 7a). The capitulum diameter is also noticeably and consistently larger in subsp. occidentalis (8-12 mm) than in subsp. discoidea (5-8 $\mathrm{mm})$.

\section{Matricaria chamomilla (Scented Mayweed)}

The achenes of $M$. chamomilla are often compressed with 4-5 thin ribs on the slightly concave or flat adaxial surface (Fig. 7d), one pair of these ribs are nearly lateral, and there are none on the convex abaxial surface (Fig. 6a, 7c). The pappus is absent or developed only as an adaxial auricle (as in Fig. 6a, 7d). The ray achenes are female and fertile (Bremer \& Humphries, 1993). Elongated and protruding cells are clearly visible on the abaxial ribs ( $\mathrm{M}$ in Fig. $6 \mathrm{~b}$ ). These correspond to the myxogenic cells described by Bremer \& Humphries (1993). In fresh materials these cells can be readily observed to swell within a few minutes when moistened.

Immature achenes possess irregular rows of glandular hairs, still visible in herbarium specimens as yellow-orange globules (arrows in Fig. 6b), they are also visible in fresh material. These ovarian glands are less readily seen in mature achenes in both fresh and preserved material and may tend to be lost or reduced prior to or during fruit formation. 

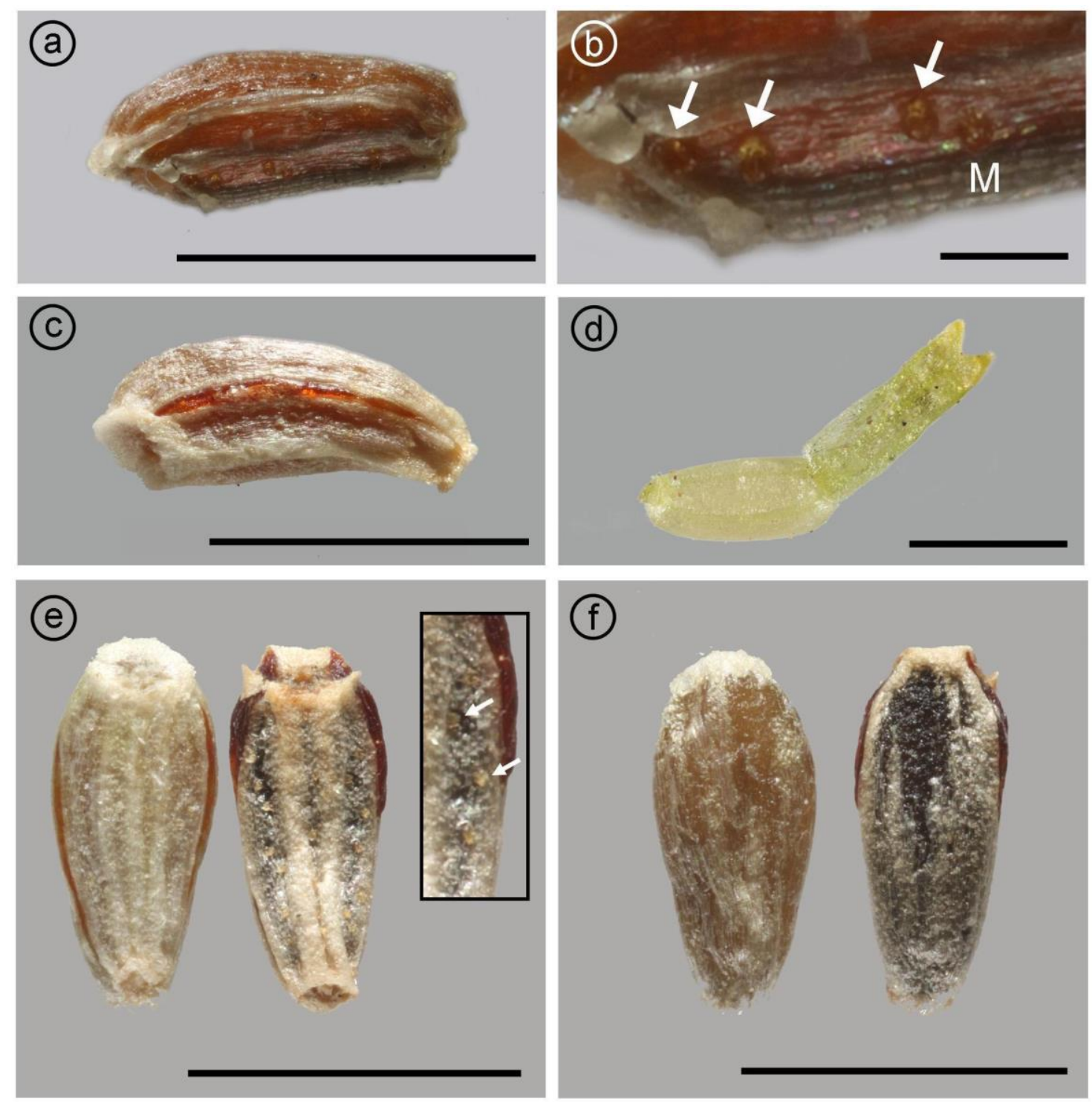

Figure 6. Achenes of Matricaria. Scale bars $=1 \mathrm{~mm}$. The apical or stylopodial end is on the left in $a, b$ and $c$, on the right in $d$ and uppermost in $e$ and $f$. a,b) Achene of M. chamomilla (v.c. 21), lateral view. The flatter/concave adaxial side is ribbed and these ribs bear rows of elongated mucilaginous cells ( $M$, seen up-close in (b)). Mature achenes sometimes retain longitudinal rows of glandular trichomes in-between the ribs, visible as yellow droplets in herbarium specimens (arrows in (b)). Note that the achene is characteristically laterally compressed. c) Achene of $\boldsymbol{M}$. discoidea subsp. discoidea, lateral view. Each achene typically has a pair of lateral glandular stripes, which are often coloured red in mature and dried specimens. Note the achene is characteristically curved with the concave surface adaxial, convex abaxial. d). A fresh immature achene of $M$. discoidea subsp. discoidea 
(collected from v.c. 15) with corolla still attached, lateral view. The darker green longitudinal veins may mark the position of future ribs and/or glandular stripes. e, f) Fresh mature achenes of $M$. discoidea subsp. discoidea (collected from v.c. 15) showing how the glandular stripes frequently extend through the pappus corona. The same two achenes are shown in adaxial view (e, note the two to three adaxial weak ribs) and in abaxial view (f, note the absence of weak ribs). The inset in (e) shows the glandular trichomes in more detail.
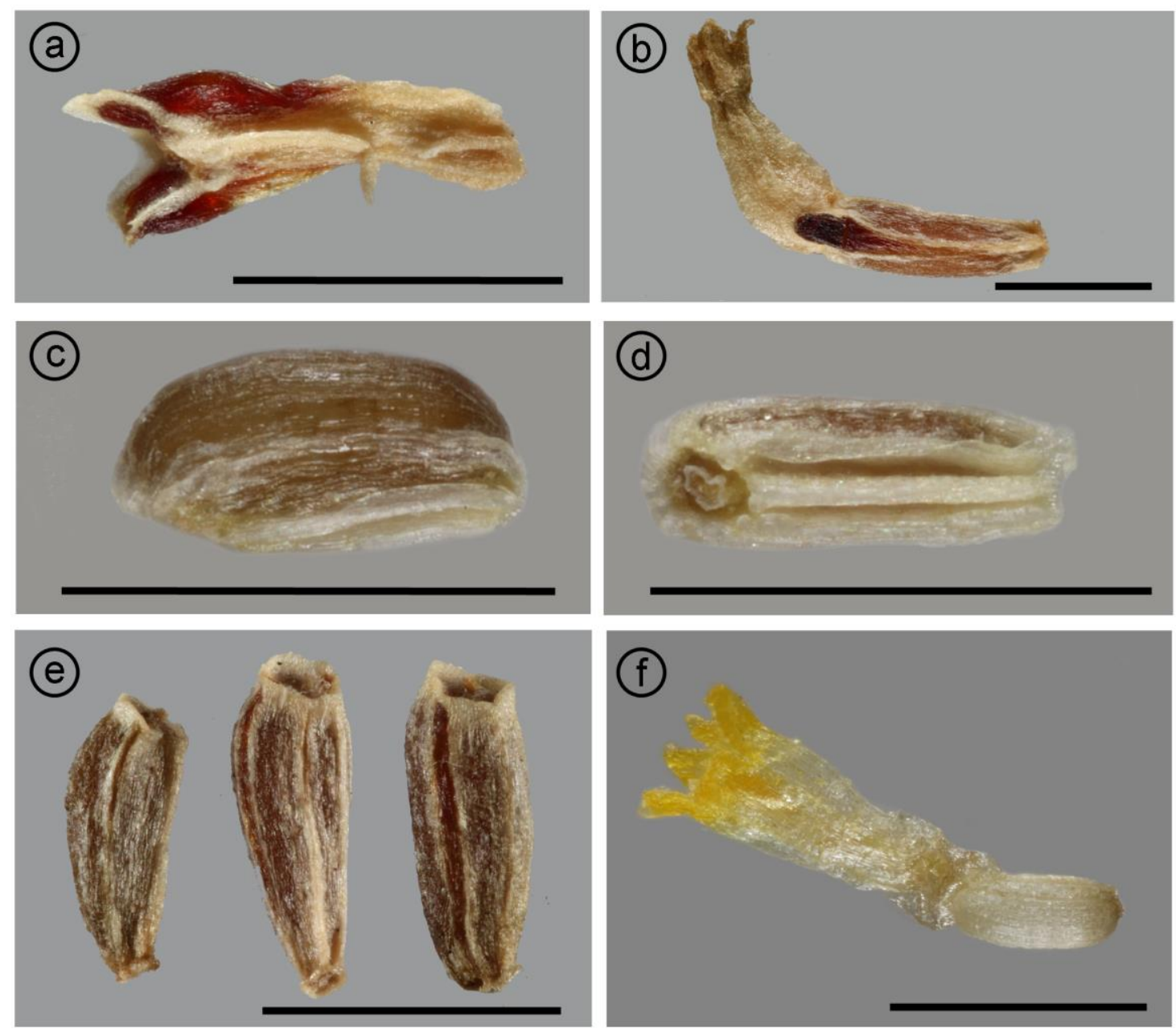

Figure 7. Matricaria achenes. Scale bars $=1 \mathrm{~mm}$. Where achenes are horizontal, the apical or stylopodial end is on the left, when vertical, it is topmost. a) Achene of $M$. discoidea subsp. occidentalis (v.c. 39). Note that the pair of lateral glandular stripes extend into prominent lateral ear-like lobes. b) Achene of $M$. discoidea subsp. occidentalis (v.c. 19) with the corolla still attached, illustrating how the lateral lobes overlap the corolla. $c$, d) Achene of $M$. chamomilla collected from a fresh specimen (v.c. 15) seen in lateral view (c) and adaxial view (d). Note that the stylopodium is clearly 


\section{visible on the left of (d). e) Three achenes of $M$. discoidea subsp. discoidea (v.c. 66) showing the variation in development of the glandular stripes. f) A very immature and fresh achene of $M$. chamomilla with the corolla still attached (collected from v.c. 15).}

Tripleurospermum maritimum (Sea Mayweed) and T. inodorum (Scentless Mayweed) It is worth noting that the disc floret corolla lobes of all Tripleurospermum species examined ( $T$. maritimum, $T$. inodorum, $T$. decipiens and $T$. disciforme) usually each bear an oil sac which in herbarium specimens is a visible reddish spot. This spot is not so easily observable in fresh material but is still present upon close examination (Fig. 8). These corolla-lobe oil sacs are a useful and reliable means of identifying Tripleurospermum species among the British and Irish mayweeds and chamomiles. The ray floret achenes in both $T$. maritimum and $T$. inodorum are described as female (Bremer \& Humphries, 1993) and are often empty-looking and undeveloped in specimens with mature disc achenes, occasionally they appear developed, suggesting variable fertility. The pappus of both T. maritimum (Fig. 9f) and T. inodorum (Fig. 10) is a corona with a wavy contour, which sometimes gives it the appearance of being formed from several fused scales.

Achenes of T. maritimum (Fig. 9b, d, f) and T. inodorum (Figs. 10b, d, f) usually have three adaxial ribs, two lateral and one medial. The pericarp on the ribs is fairly smooth but is rugose abaxially and between the ribs. The achenes of T. maritimum are also often visibly much larger than those of $T$. inodorum with approximate reported ranges in length of 1.8 to $3.5 \mathrm{~mm}$ for the former and 1.3 to $2.2 \mathrm{~mm}$ for the latter (Stace 2010, 2019; Kay 1972).

Tripleurospermum achenes usually have 2 (occasionally 1 to 4 or 5 ) abaxial-apical 'oil glands' (Stace, 2010) or 'resin sacs/glands' (Brouillet, 2006b) (Figs. 1, 8). The term 'oil sac' seems the most apt and we shall use this term here. These oil sacs appeared brown or red in herbarium specimens, they are initially green in fresh, unripe achenes. When examining fresh material collected from $T$. inodorum and T. maritimum (subspp. maritimum and subsp. vinicaule) we observed that the very immature achenes of both species are whitish translucent with bright green oil sacs (Fig. 9e). When fully mature, they have very dark brown pericarps and red to almost black oil sacs (Fig. 10h). These dark oil sacs are only found in the most mature capitula and often the full colour range is evident at the point at which the achenes start to detach, suggesting that these colour changes occur over a few days after detaching from the receptacle. Indeed, the oil sacs and pericarps were seen to continue to darken several days after removal of the achenes. During our work, we noted that this colouration is not due to the oil contained within, which stains white filter paper a bright yellow, but reflects changes in the cells of the pericarp wall overlying the oil. The achene wall generally darkens during ripening (Figs. 11,12) with the most mature achenes often turning a very dark-brown which sometimes makes the oil sacs hard to distinguish based on colour alone (Figs. 11, 12a). 


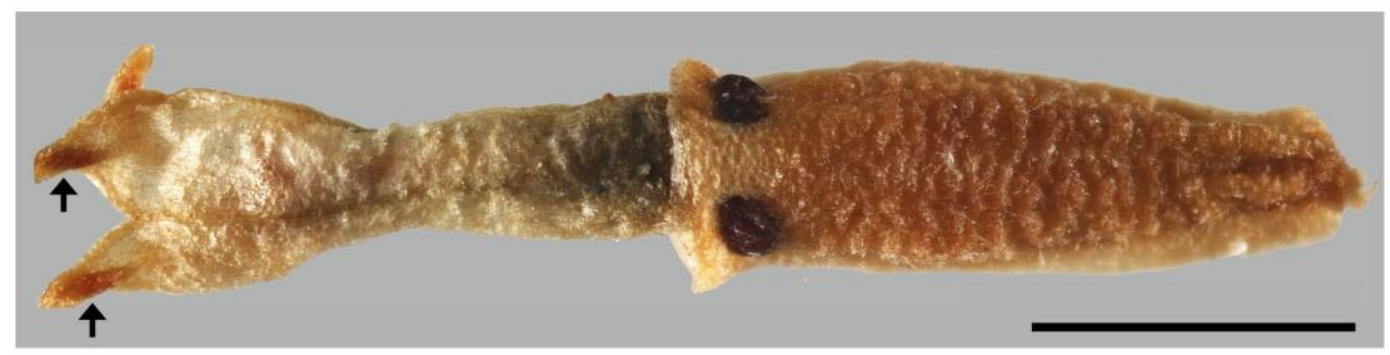

Figure 8. An immature achene of T. inodorum (v.c. 16) with corolla still attached on the left. Note the oil sacs (dark structures indicated by arrows) one in each corolla lobe, which is characteristic of many Tripleurospermum spp., including all those native to Britain. Scale bar $=1 \mathbf{~ m m}$.
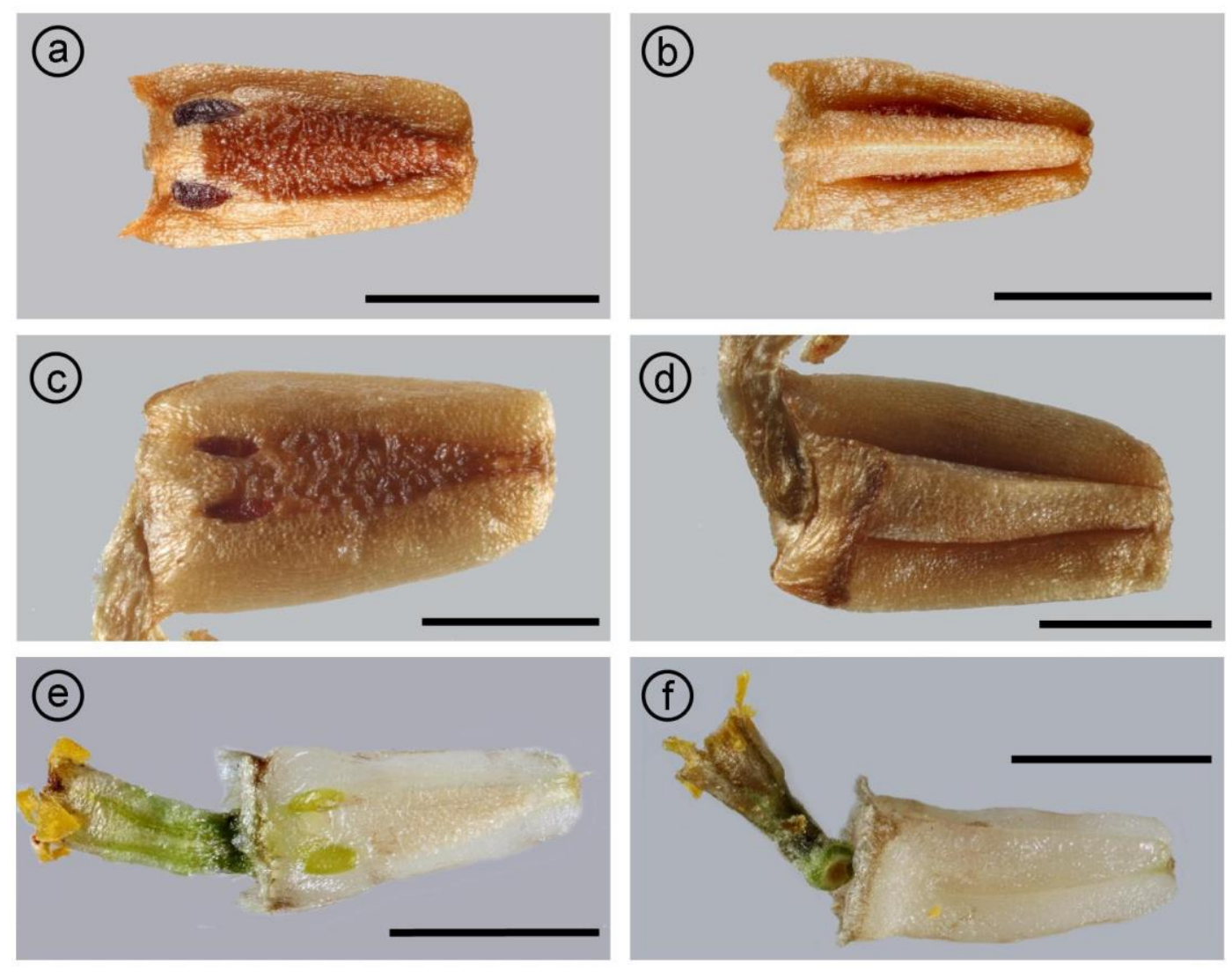

Figure 9. Tripleurospermum maritimum achenes, scale bar $=1 \mathrm{~mm}$; apical or stylopodial ends leftmost. a) Achene of $T$. maritimum subsp. maritimum (v.c. 2), abaxial view. Note the pair of elliptical oil glands, the corona or crownlike pappus and the characteristic rugose texture. b) The same achene (a) in adaxial view. Note the three characteristic ribs. c) An achene of $T$. maritimum subsp. nigriceps (v.c. 107), abaxial view. d) The same achene (c) in adaxial view. e) An immature achene of $T$. maritimum collected fresh from Medmerry (v.c. 13) (abaxial view). f) Adaxial view of the same achene as (e). 
In T. maritimum each of the pair of abaxial-apical oil sacs is more than 1.5 times as long as wide (Kay, 1972) (Fig. 9a). Generally, if the oil sacs are 2 or more times as long as their width then this is a strong indication that the specimen is T. maritimum. In contrast, the oil sacs of T. inodorum are shorter and more rounded (Fig. 10a). Kay (1972) however, considered this a slightly unreliable character and also relied upon the size and separation of the two lateral and single adaxial medial ribs when making determinations. In the same publication, Kay provided a visual scale to aid identification based on oil sac shape as well as rib size and separation. The ribs are much more strongly developed in T. maritimum (Figs. 9b, d) with much less space (narrower furrows or sulci) between them. We found this a useful character, but we based our determinations primarily on oil sac shape and secondarily on rib separation and achene size. Plants which could not be determined with certainty based on these characters, or in which the characters obviously conflicted, were set aside as possible hybrids between T. inodorum and T. maritimum (see below).

Care should be taken when determining immature achenes. The achenes first attain their final length before other aspects of maturation (particularly oil sacs and ribs) occur. Thus, immature achenes with rounded oil sacs correspond to $T$. inodorum, but apparently elongated oil sacs (comparable to the mature ones of $T$. maritimum) may widen after further development and attain a rounded contour. Therefore, care should be exercised when determining a specimen as T. maritimum from immature achenes. It should also be noted that the ribs of $T$. maritimum become quite distinctive and relatively well-developed early on during maturation (Figs. 9f, $12 b$ ), though one should be cautious to make firm determinations from very immature material. The ribs of $T$. inodorum are also relatively distinct early on in development (Figs. 10d, 11b).

Occasionally, specimens with anomalous numbers of oil sacs occur (Fig. 13a, b). These specimens may have three or four oil glands and some keys cite the range as 15 , with 1 occurring as the result of fusion of two or more glands (Bremer \& Humphries, 1993). We found several such specimens in the Natural History Museum. One specimen of $T$. inodorum, collected from v.c. 111 in 1889 , had no oil sacs on any of the achenes examined, however the achenes were morphologically typical in all other respects (Fig. 13e).

The ribs of Tripleurospermum achenes are a significant diagnostic feature. Although our determinations were based mainly on oil sac shape, the nature of the ribs may be at least as reliable. Sometimes these two characters are inconsistent, as described below for potential hybrids or specimens of $T$. maritimum showing introgression of $T$. inodorum in which the characters are reportedly sometimes mixed. Kay (1972) examined flotation in Tripleurospermum achenes and found that $T$. maritimum achenes floated much more readily in water than those of T. inodorum; they also maintained viability for longer in water (at least 8 months). This flotation ability Kay attributed to the large 'spongy' ribs of T. maritimum as an adaptation for assisting dispersal in a coastal habitat. Many populations are close enough to the highest driftline to be dispersed by winter storms (Kay, 1972). Bremer \& Humphries (1993) 
reported occasional specimens with 1-2 thin supernumerary abaxial ribs, we also found several such examples in the herbarium (Fig. 13c, d). One specimen of T. maritimum collected from Weymouth (v.c. 9) had one thin and medial supernumerary abaxial rib and the oil sacs were so small as to be apparently absent in some achenes. This reduction in the normal dorsoventral asymmetry, which occurs during normal development, resulted in a tendency for both faces to appear 'adaxial' in character.
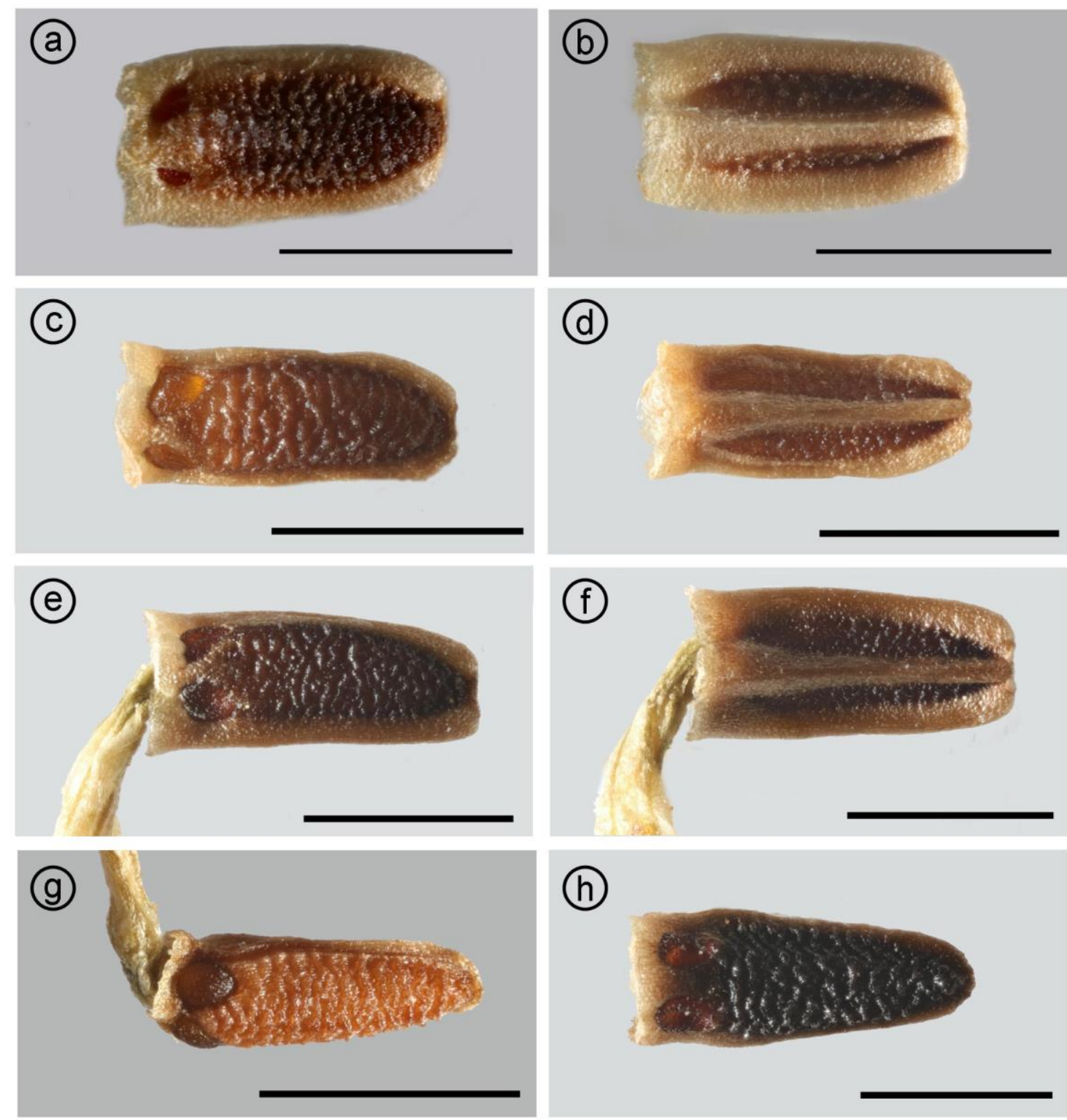

Figure 10. Tripleurospermum inodorum achenes, scale bars $=1 \mathrm{~mm}$; the apical stylopodial ends are leftmost. a) Achene of T. inodorum (v.c. 9), abaxial view. Note the pair of circular oil glands (not elongated or elliptical as in T. maritimum) the corona or crown-like pappus and the characteristic rugose texture. b) The same achene as in (a) in adaxial view. Note the three 
characteristic ribs (which are much thinner and more widely spaced than in T. maritimum). (c) - (h) are $T$. inodorum achenes from freshly collected material (from v.c. 15) showing colour variations. c) Partially ripened achene, note the orange colouration of the oil glands; abaxial view. d) The same achene (c), abaxial view. e) A partially ripened achene with corolla still attached, abaxial view. f) The same achene (e), adaxial view. g) An immature achene with corolla tube still attached, abaxial view. h) A more mature achene, note the difference in colour to $(\mathrm{c})$ and $(\mathrm{g})$ : the achene in $(\mathrm{h})$ is more darkly coloured and the oil glands are red and somewhat sunken; abaxial view.

\section{Subspecies of T. maritimum}

Tripleurospermum maritimum is widespread around the coasts of Britain and Ireland where it is largely represented by subsp. maritimum. Along the coast of southern England and the Channel Islands this is generally replaced by subsp. vinicaule whilst in northern Scotland, Orkney and the Shetland Islands subsp. nigriceps occurs (Sell \& Murrell 2006, Stace 2019). The latter subspecies can be determined by its characteristic phyllaries, which have dark brown scarious margins that are $0.4 \mathrm{~mm}$ or more in width. In contrast, subsp. maritimum and subsp. vinicaule have phyllaries with pale brown to brown scarious margins less than $0.3 \mathrm{~mm}$ wide (Stace, 2019). Since phyllary margins may shrink and fray in herbarium specimens, several measurements should be taken, however, some specimens were easily identifiable as subsp. nigriceps.

The third subspecies, vinicaule, is separable by the extent of the intense purplishred of the stems and the form of the ultimate leaf segments (Sell \& Murrell 2006, Stace 2019). We were able to determine several herbarium specimens of subsp. vinicaule. However, some specimens from the same locality had much less intense colouration and could not be determined with certainty as subsp. vinicaule. Kay (1972) noted that some plants determined as subsp. vinicaule had less pigmentation. It is also probable that vinicaule and maritimum freely hybridise and intergrade.

Kay (1972) reported an 'irregular cline' in achene size in pure populations of $T$. maritimum s.l., with achene size decreasing from east to west along the south coast of England, with the smallest varying in mean length between about 2.0 and $2.5 \mathrm{~mm}$. Achene size also increased northwards, reaching a maximum in western Scotland (with a mean length between 2.5 and $3 \mathrm{~mm}$ in some populations. Therefore, it is probable that subsp. nigriceps has achenes with larger mean dimensions. Of the BM specimens identified with certainty as nigriceps, the achenes are frequently large and within the 2.6 to $3.2 \mathrm{~mm}$ range, which is consistent with Kay's observations (Fig. 9c, d), but more samples are required to verify this with certainty. One specimen of subsp. maritimum, collected from v.c. H39 in 1928, had unusually large achenes, measuring about 3.5 to $3.6 \mathrm{~mm}$ in length, so it cannot be concluded that the size difference is clear-cut, but there may be a general mean size difference. Other than possible size differences, there are no apparent morphological differences in the achenes between the three subspecies 
of T. maritimum. Achenes of T. inodorum from v.c. (107)110-112 were frequently also large with a characteristic morphology (Figs. $13 \mathrm{~g}, \mathrm{~h}$ ).
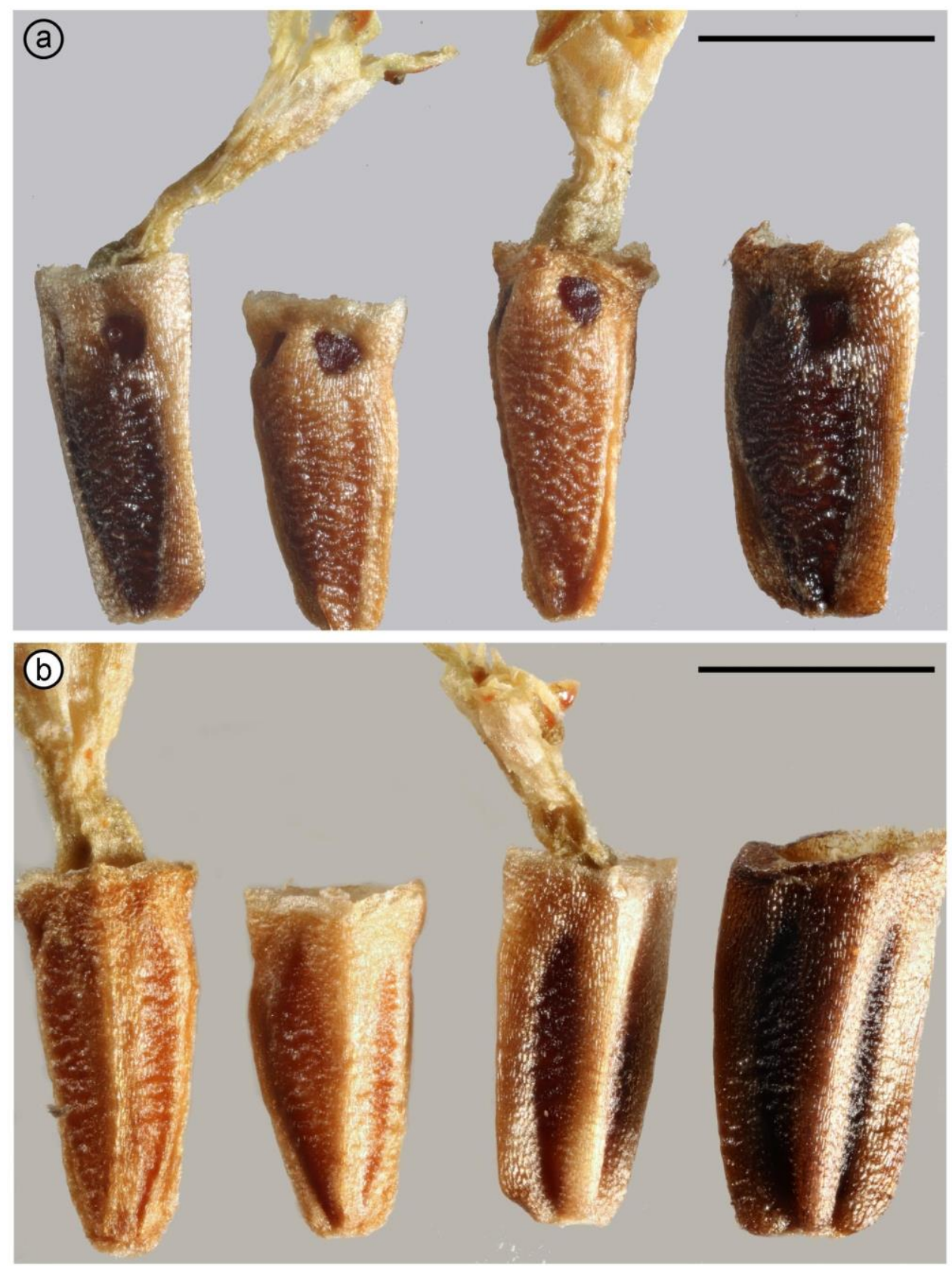

Figure 11. Maturation of $T$. inodorum achenes. Scale bars $=1 \mathrm{~mm}$. The apex or stylopodial end is uppermost in each achene. $a, b$ ) Four achenes of $T$. inodorum collected from the same plant (v.c. 9) in abaxial (a) and adaxial (b) views, showing different stages of maturation (development increasing from left to right). Note the variation in width and rib development. 

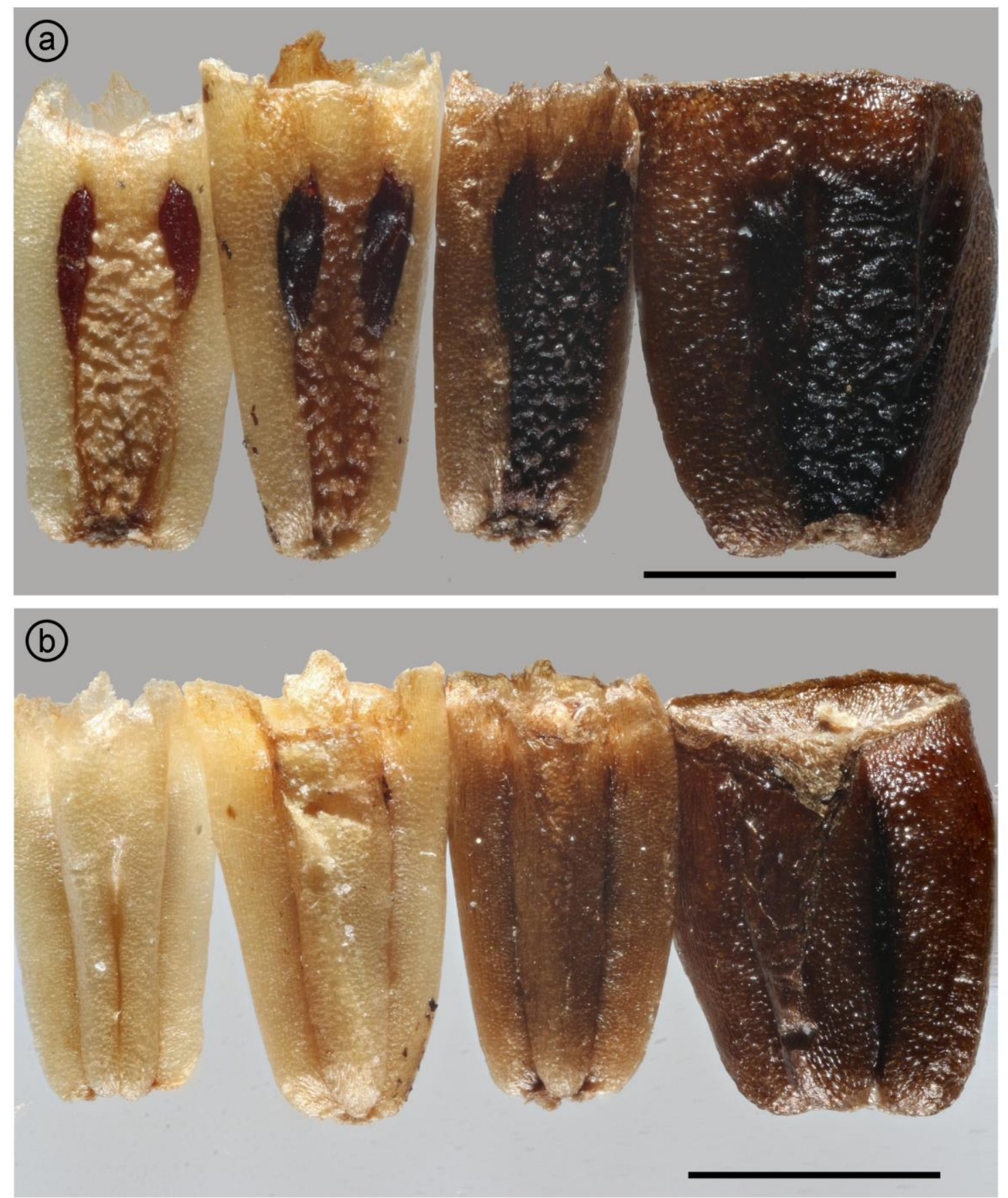

Figure 12. T. maritimum achene maturation. Scale bars $=1 \mathrm{~mm}$. The apex or stylopodial end is uppermost for each achene $(a, b)$. Four achenes of $T$. maritimum subsp. maritimum from the same plant (v.c. 41) in abaxial (a) and adaxial (b) views, showing different stages of maturation. Notice the variation in width and rib development and the variation in colour with the larger more mature achenes (rightmost) having darker colouration. However, the elongation of the oil glands is often evident early on, as here. 

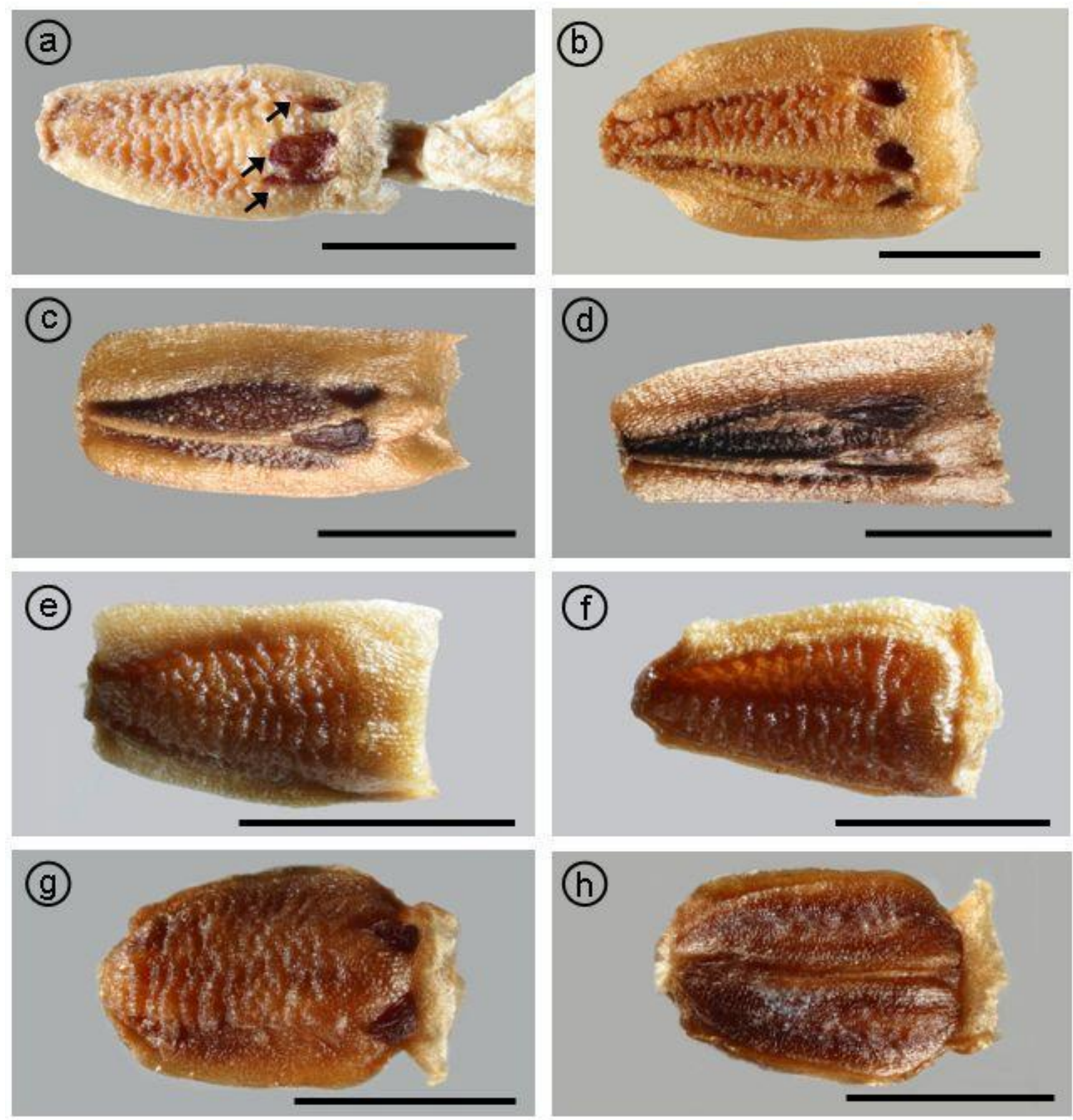

Figure 13. a to f: abnormalities of achene development in Tripleurospermum. Scale bars $=1 \mathrm{~mm}$. The apical or stylopodial ends are rightmost. The abnormalities shown by (a) to (d) occurred in only a minority of the achenes sampled from the specimen. In contrast, (e) and (f) are from a plant in which all of the achenes lacked oil glands. Scale bars $=1 \mathrm{~mm}$. a) An achene of $T$. inodorum (v.c. 111), in abaxial view, with three oil glands instead of the usual two, due to the doubling up of one of the glands to form a pair. This is a relatively common abnormality. b) An achene of $T$. maritimum with evidence of introgression from $T$. inodorum (short oil sacs but very thick adaxial ribs) (v.c. 82), in abaxial view, with three oil sacs which developed 
separately, and an extranumerary thin abaxial rib. c) An achene of $T$. maritimum subsp. maritimum (v.c. 21), abaxial view, with an additional weakly developed rib situated on the abaxial face. The rib extends from one of the oil glands. d) An achene of T. maritimum subsp. maritimum (v.c. 21), abaxial view, with one pair of additional weakly developed ribs on the abaxial face, each extending from one of the oil glands. e) An achene from a specimen determined as $T$. maritimum subsp. maritimum (v.c. 111) possibly introgressed with subsp. phaeocephalum, abaxial view. Note the complete absence of oil glands. f) A second achene from the same plant as (e) which, in common with all the achenes sampled from this plant, completely lacked oil glands. Figs. g) and h) show an achene morphology of T.inodorum frequent in specimens from the most northern parts of the British Isles (v.c. $(107,110$ - 112); this specimen was collected from v.c. 112 and is shown in abaxial $(\mathrm{g})$ and adaxial $(\mathrm{h})$ views; note the large breadth of the achene which exceeds that of the narrower pappus; the apical or stylopodial ends are rightmost.

\section{Hybridisation betweenTripleurospermum maritimum and T. inodorum}

The hybrid between T. maritimum and T. inodorum is noted as occurring not infrequently in coastal areas (Stace, 2019; Stace et al., 2015) and is described as intermediate in leaf and achene characters. Hybrid plants are typically $50-80 \%$ fertile (Kay, 1972). When determining specimens, material referable to either T. inodorum or T. maritimum, we primarily based our determinations on achene characters such as oil sac shape, rib spacing and overall achene size. We also considered the leaf morphology and habit of the plant. These latter characters can be challenging to use in herbarium specimens. Most specimens could satisfactorily be determined as either T. maritimum or T. inodorum. However, some specimens were ambiguous and were noted as possible hybrids. These plants displayed a variety of anomalous characters such as: individual achenes with traits indicative of both species, these sometimes differed from achene to achene on the same plant or even on the same capitulum. Examples of these anomalous character distributions included very variable oil sac form on achenes of a specimen collected from Berkshire (v.c. 22) in 1895, whilst a specimen collected from v.c.107 in 1907 had circular oil sacs (Fig. 14a, c) but large and closely spaced ribs (Fig. $14 b, d)$.

To verify the likelihood of our suspected hybrids the geographic ranges of the putative parents were considered (Stace et al., 2015) and Kay's (1972) semiquantitative scale for achene characters was used. For example, one specimen labelled as T. inodorum collected from a cultivated field in Keswick (v.c. 70) had very welldeveloped ribs, characteristic of $T$. maritimum, but with circular oil sacs characteristic of T. inodorum, however, T. maritimum has not been recorded at this inland site. Using Kay's scale, most of the achenes sampled from this specimen scored 1.5 on oil-sac shape/elongation (= inodorum) and 4 on rib thickness (= maritimum), thus indicating mixed parentage. However, the habit and leaves of this specimen suggested $T$. 
inodorum and this specimen was determined as $T$. inodorum, with some signs of introgression.

Following a report that in the Orkneys there are more hybrids than either $T$. inodorum or T. maritimum parents (J. Crossley, cited in Stace et al., 2015) we examined achenes from specimens in the herbarium from the Orkneys and Shetlands for indications of hybridity. The few specimens filed as T. maritimum subsp. nigriceps exhibited both typical and atypical achenes. The atypical achenes had either small ribs with maritimum-like elongated oil sacs (v.c. 111) or very large ribs with circular oil sacs. Because these islands are within the latitudes in which subarctic T. maritimum subsp. phaeocephalum (which is not currently recognised as being present in Britain or Ireland) occurs, we also examined museum specimens of subsp. phaeocephalum from Iceland and Scandinavia for comparison. Achenes sampled from these specimens had very variable rib thickness, spanning the whole spectrum from the thinnest found for $T$. inodorum to the thickest for $T$. maritimum, though more often thin, and circular oil sacs or very small or absent oil sacs. The specimens in the General Herbarium have not been consistently worked upon and it is probable that many of these specimens are misidentified, thus rendering comparison with British and Irish populations less reliable.

Interestingly, one specimen from the Orkneys completely lacked oil sacs (Fig. 13e) on all achenes examined which makes it unique within the herbarium. Examination of the Islandic and Scandinavian specimens filed as T. maritimum subsp. phaeocephalum revealed that of seven specimens with mature achenes, two lacked oil sacs on all achenes sampled (both from Iceland), three had some achenes lacking oil sacs and two had the usual elongated oil sacs typical of T. maritimum (two from Iceland and one from Norway) suggesting that the tendency to lack oil sacs may be a characteristic of these subarctic European populations.

This raises the possibility that the Orkney specimen comes from a population with some introgression from T. maritimum subsp. phaeocephalum.

\section{Tripleurospermum decipiens and Tripleurospermum disciforme}

In the Flora of Pakistan, Quaiser (2006) describes the achenes of T.decipiens as noticeably smaller and slenderer (1 to $1.5 \mathrm{~mm}$ ) than those of T. inodorum (1.4 to 2.3 $\mathrm{mm}$ ) (Kay 1972, 1994). The ribs of T. decipiens (Fig. 15d) and T. disciforme (Fig. 15b) are also relatively very thin compared to $T$. inodorum (Fig. 10b, d, f). Based on observations of specimens from Iran and Kurdistan in the General Herbarium at the Natural History Museum the achenes of $T$. disciforme are also noticeably smaller than those of $T$. inodorum. Furthermore, the abaxial face of achenes in T. disciforme are smooth (Fig. 15a) whereas those of $T$. decipiens are rugose (Fig. 15c) like those of $T$. inodorum and T. maritimum. 

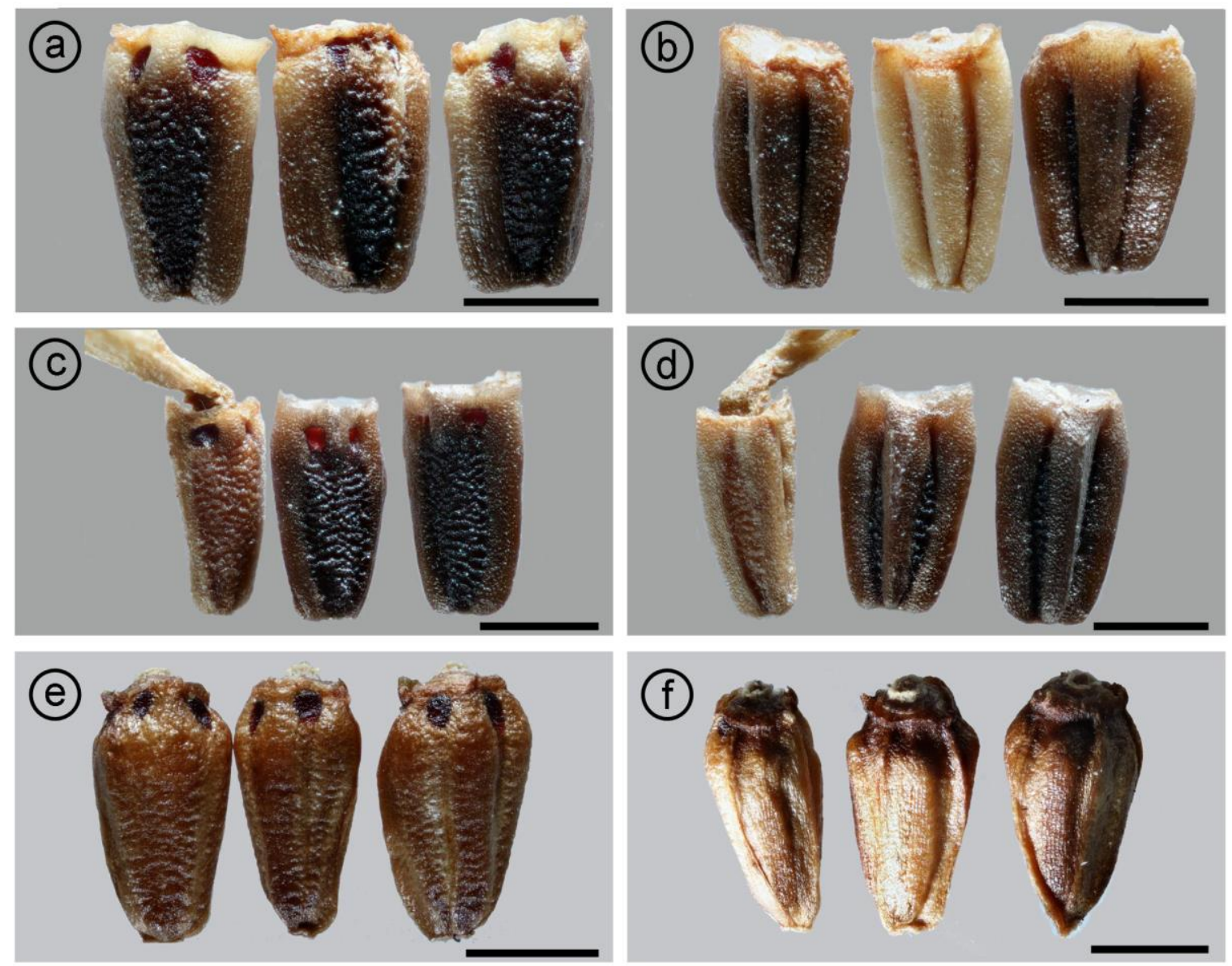

Figure 14. Putative hybrid Tripleurospermum achenes. Scale bars $=1 \mathbf{~ m m}$. a,b) Tripleurospermum (v.c. 13) achenes from a single plant, in which the oil glands were circular (a) abaxial view, characteristic of $T$. inodorum, but with the ribs very well developed and closely spaced (b) adaxial view, characteristic of T. maritimum. C, d) Some specimens (v.c. 21), previously determined as $T$. inodorum, had the characteristic circular oil glands of $T$. inodorum but reasonably well-developed ribs (akin to $T$. maritimum). These three achenes are all from the same plant (from v.c. 63/64) seen in abaxial view (c) and adaxial view (d). e, f) These achenes were all from the same plant (v.c. 112) which was unique in the BM collection for having achenes with a strong tendency to radial symmetry, resembling those of Anthemis. Note the reduced pappus with a tendency towards better adaxial development. However, the abaxial view (e) is more rugose and possesses oil glands as in Tripleurospermum. It is possible that this plant is a $\mathrm{X}$ Anthepleurospermum (Anthemis x Tripleurospermum) hybrid. 

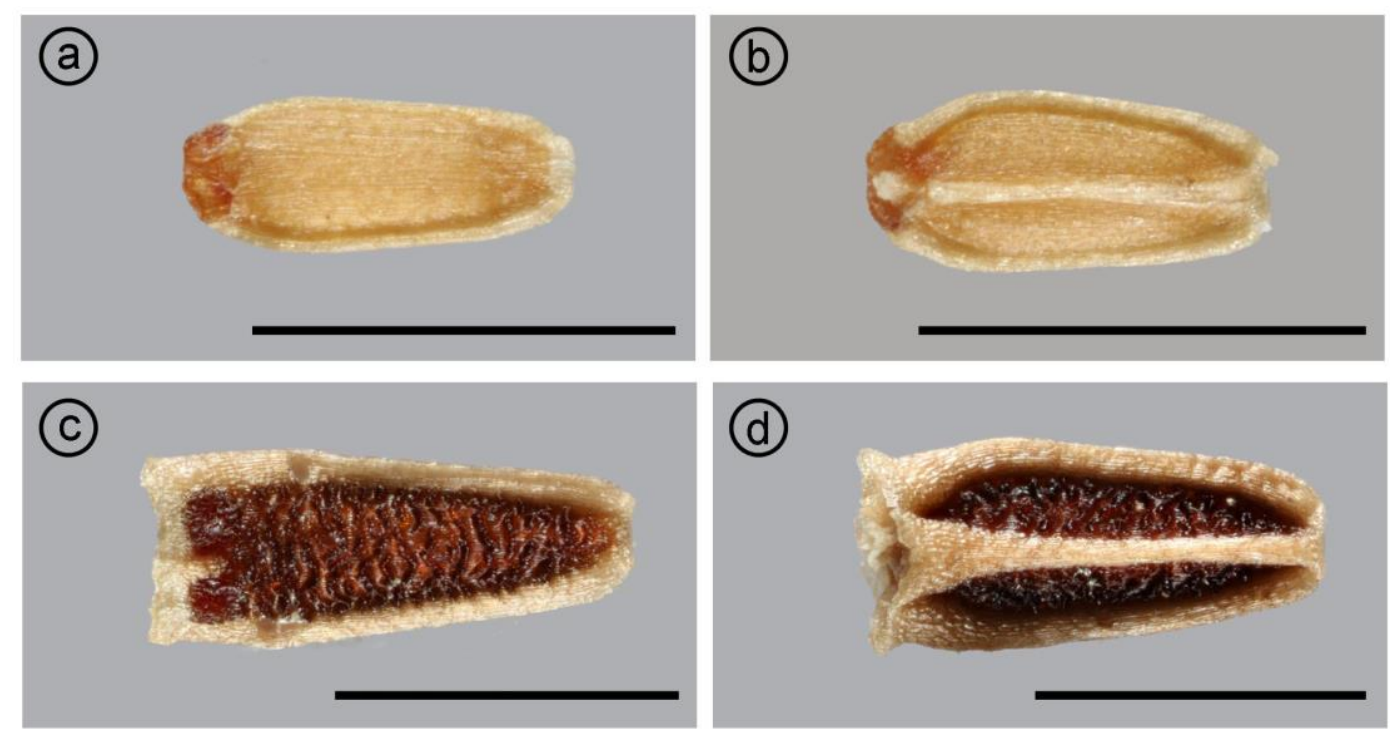

Figure 15. Other species of Tripleurospermum occasionally found in the Britain and Ireland, herbarium specimens; the apical or stylopodial ends are leftmost. Scale bars $=1 \mathrm{~mm}$. a) An achene of $T$. disciforme (from W. Asia), abaxial view. Note the slender size of the achene and the complete lack of a pappus. b) The same achene as (a), adaxial view; note the thin ribs. c) An achene of T. decipiens (v.c. 6), abaxial view; note the presence of the pappus corona distinguishes this species from $T$. disciforme (a) and (b). d) The same achene as (c), adaxial view; note the thin ribs.

There were 13 specimens of rayless Tripleurospermum filed as $T$. decipiens in the British and Irish Herbarium (2 from v.c. 6; 2 from v.c. 9; 1 from v.c. 39; 1 from v.c. 54; 5 from v.c. $61 ; 2$ from v.c. 63 and 1 from an unknown location). Twelve of these specimens were determined by us as $T$. decipiens. These specimens have a pappus corona (Fig. 15c, d) similar to the coronas of T. maritimum and T. inodorum. A singlespecimen had immature achenes which totally lacked a pappus of any type (Fig. $15 a, b)$ resulting in the oil sacs visibly protruding from the top of the achene. This specimen was determined as T. disciforme (collected from v.c. 17 in 1839). These observations agree with the descriptions given in the Flora of Pakistan (Quaiser 2006). Quaiser (2006) also reports that the achenes of $T$. disciforme are myxogenic, though no obvious myxogenic cells could be discerned in our specimens. It is worth noting that $T$. decipiens has recently been recorded in Antwerp, Belgium between 2011 and 2014 (Verloove, 2015). There is also a 2004 record from v.c. 32 (BSBI Database accessed $25 / 01 / 2018)$, it is therefore possible that this species will occur elsewhere in Britain or Ireland.

\section{Achene Key}

We have compiled a dichotomous key for the mayweeds and mhamomiles most likely to be encountered in Britain and Ireland. This key is based, as far as possible on achene 
morphology, specifically the disc achenes, but separates $C$. tinctoria on the basis of ligule colour, which is evident even in herbarium specimens. However, the squarish contour of tinctoria achenes, when viewed from the stylopodial pole are fairly distinctive but not unique, since the achenes of $C$. austriaca are also quadrangular, but more compressed when mature.

$1 \quad$ Ligules yellow (in both fresh and herbarium specimens); achenes typically quadrangular when viewed end-on, with more than 6 (obvious) ribs, typically 2 on each of the four sides and 4 along the angles...

Cota tinctoria

1 Ligules white, not yellow (some discolouration may occur in old or poorly stored herbarium specimens)...

2 Oil sacs or oil canals present on achene surface...

2 Oil sacs or canals not present on achene surface (though the achene may have glandular hairs)...

3 (1-)2(-5) abaxial-apical oil sacs extending less than half the length of achene and situated between ribs...

$\begin{array}{lll}3 & 2(-4) \text { oil canals extending along most of achene length along ribs... } & \mathbf{6}\end{array}$

4 Corolla tube has a basal swelling which partially overlaps the achene... $\quad \mathbf{7}$

4 Corolla tube does not overlap achene...

5 Oil sac length less than 1.5 times the width of oil sac...

5 Oil sac length greater than or equal to 1.5 times the width of oil sac...

6 Achene apex with two distinct lateral extensions or lobes (into which oil canals may extend)...

M. occidentalis

6 Achene apex with a small rim (reduced pappus), without distinct lateral extensions...

M. discoidea

7 Corolla lobe base overlaps the apex of the achene only, more-or-less symmetrically on all sides...

Chamaemelum nobile

7 Corolla lobe base extends far over the one face (adaxial face) of the achene...

Chamaemelum mixtum

8 Achene with 4-5 thin, weak ribs on the slightly concave or flat adaxial face only, longitudinal rows of prominent myxogenic cells present; pappus absent or short auricle...

M. chamomilla

8 Achene either not ribbed or is ribbed on both adaxial and abaxial surfaces... 9 
9 Achene distinctly abaxially-adaxially compressed, 6 or fewer ribs (exclude weak ribs of the same colour as the pericarp); 2-3 prominent ribs on each face (abaxial and adaxial); pappus a rim or very short corona...

Cota austriaca

9 Achene not distinctly compressed abaxially-adaxially (may be turbinate, obovate, conical or squarish)...

10 Ribs very strongly developed and separated abaxially by less than the width of the medial rib, possibly...

T. maritimum $\times$ T. inodorum

10 Ribs moderately developed and separated by tissue equal to or greater than the width of the median rib...

T. inodorum

11 Ribs very strongly developed and separated abaxially by less than the width of the medial rib...

T. maritimum

11 Ribs moderately developed and separated by tissue equal to or greater than the width of the median rib, possibly...

T. maritimum x T. inodorum

12 Pappus, on the adaxial side $0.3 \mathrm{~mm}$ to $1 \mathrm{~mm}$; the achene not or weakly ribbed...

12 Achene pappus or short corona, rim, auricle or absent...

A. punctata

13 Ribs frequently tuberculate; pappus absent or greatly reduced; achene apex rounded...

A. cotula

13 Ribs smooth, not tuberculate; pappus a very short corona or rim...

A. arvensis

\section{Discussion}

Should M. discoidea subsp. occidentalis be treated as a separate species?

There are striking morphological differences between the achenes of $M$. discoidea subsp. discoidea and M. discoidea subsp. occidentalis, the extended lateral oil canals of occidentalis were consistently observed in all specimens examined. No intermediate forms were observed; although there were relatively few specimens of subsp. occidentalis in the herbarium. In addition, the capitula of subsp. occidentalis are distinctively larger (8-12 mm) compared to specimens of subsp. discoidea (5-8 mm) these observations are consistent with those given in Stace (2019). Due to the significant size difference, it was easy to pick out subsp. occidentalis specimens by capitula size alone. Subsequent checks of achene characters confirmed these provisional determinations.

In North America M. discoidea subsp. occidentalis is considered as a separate species, M. occidentalis, from M. discoidea. M. discoidea S.S. is native to northwestern North America but has spread to eastern and northern North America. It is ruderal, even in its native range, as it is in Britain and Ireland, making its native habitat difficult to ascertain. M. discoidea subsp. occidentalis has a rather narrower native distribution 
being largely confined to California and Oregon where it appears restricted to undisturbed alkali flats, vernal pools and the edges of salt marshes. M. discoidea subsp. discoidea is well known for its aromatic foliage and inflorescence, apparently $M$. discoidea subsp. occidentalis is scentless (Brouillet, 2006a). Whilst both taxa have the same reported number of chromosomes, $2 n=18$ (Brouillet, 2006a), we believe this is insufficient grounds for retaining occidentalis as a subsp. of discoidea.

The clear morphological differences when combined with the different native habitats and (partially) distributions of these plants suggest that they warrant recognition as separate species as in the Flora of North America (Brouillet, 2006a).

\section{Potential introgression of T. maritimum subsp. phaeocephalum with British}

Tripleurospermum populations

The unusual achenes sampled from some Tripleurospermum specimens from v.c. 109, 111 and 112 had features which may be attributable to introgression between $T$. inodorum and T. maritimum or introgression of either of these species with $T$. maritimum subsp. phaeocephalum. The Scandinavian and Icelandic specimens of subsp. phaeocephalum we examined frequently had achene characteristics, namely thin ribs and elongated oil sacs, similar to those of the inodorum $x$ maritimum hybrid. A Tripleurospermum specimen from the Orkneys (v.c. 111) completely lacked oil sacs on all examined achenes, this absence of oil-sacs was also observed in a surprisingly high proportion of T. maritimum subsp. phaeocephalum from the sub-arctic collections from Iceland. Of these specimens, 2 of 7 had no oil-sacs at all, a further 3 had many achenes lacking oil-sacs and only 2 specimens consistently had them on all achenes examined). This may be a trait found in some phaeocephalum populations and may be an adaptation to low temperatures. More work, involving genetic and detailed morphological analyses, needs to be done before the extent of potential phaeocephalum introgression in these northern-most populations can be confirmed.

\section{Achenes and the taxonomy of Anthemis}

The taxonomy and nomenclature of the Anthemidae is still rather unsettled although recent work by Oberprieler (2002) and Lo Presti et al., (2010) has made significant advances. The phylogenetic analyses by Lo Presti et al., (2010) of Anthemis s.l. based on nuclear and plastid DNA markers as well as micromorphological traits determined by principal coordinate analyses established the basis for a new taxonomic arrangement that saw the recognition of a new genus (Archanthemis Lo Presti \& Oberpr.) and the transferal of other species to the 'historic' genus Cota J. Gay ex Guss. None of the species in our study are referable to Archanthemis but some are included within Cota. The affected species are: $A$. altissima ( $=C$. altissima (L.) J.Gay), $A$. austriaca $(=C$. austriaca (Jacq.) Sch.Bip.) and $A$. tinctoria (= C. tinctoria (L.) J.Gay). It is worth noting that there are some incongruences between the phylogenic trees based on nuclear and chloroplast markers which led Lo Presti et al., (2010) to suggest that hybridisation has been an important driver in the evolution of the Anthemis s.l. complex. Whilst there are sound grounds for accepting Cota based upon DNA and micromorphological characters, 
the genus is difficult to define morphologically and devising a key that satisfactorily separates Cota from Anthemis s.s. may be challenging to devise. Nevertheless, recent continental workers (Tison \& Foucault, 2014, Verloove 2012b) and Stace (2019) have accepted Cota as a valid genus. Stace (2019) distinguishes Cota from Anthemis principally by the dorsiventrally (abaxially-adaxially) compressed achenes of Cota.

We encountered problems when determining achenes of $A$. punctata as belonging either to subsp. punctata or subsp. cupaniana. The reference to cupaniana achenes as being 'not granulate' and subsp. punctata achenes as being 'granulate' (Tutin et al., 1976) was not helpful. Initially, comparison of British herbarium specimens with European and North African material from the BM collection proved inconclusive. Oberprieler (1998 and pers. comm.) clarified the ambiguity, the achenes of subsp. cupaniana are generally smooth (non-tuberculate), whereas those of subsp. punctata are generally considered to be tuberculate. Oberprieler found that subsp. cupaniana from Sicily had smooth achenes, and that subsp. punctata in Tunisia and E. Algeria also tended to have smooth achenes. However, in subsp. kabylica from central Algeria, the achenes were tuberculate. Oberprieler concluded that there may be a continuous cline and that tuberculation is a variable character within subspp. punctata and kabylica. He also found, however, that the species can be distinguished based on differences in phyllary shape (narrow in cupaniana, obovate in punctata and narrow in kabylica). More recently, Lo Presti et al. (2010) have elevated the Italian plants (subsp. cupaniana) to specific rank as $A$. cupaniana Tod. ex Nyman based upon the results of their phylogenetic analyses. Based on their lack of tuberculation we were able to confirm that all British herbarium specimens were indeed $A$. punctata subsp. cupaniana.

\section{Achenes and the taxonomy of Chamaemelum}

Chamaemelum fuscatum, C. mixtum and $C$. nobile have achenes with significant morphological similarities, such as basal swellings of the corolla tube which partially enclose the apex of the achene, Achenes of these taxa also have a rounded apex, a thin non-sclerenchymatous pericarp bearing longitudinal rows of myxogenic cells and a monosporic embryo sac (Briquet, 1916). This contrasts with Anthemis and Cota which are characterized by achenes with thick, sclerenchymatous pericarps and truncate or flattened apices, presence of myxogenic cells in many species, and (along with Tripleurospermum) a tetrasporic embryo sac (e.g. Cota tinctoria, Bijok et al., 1977). A molecular phylogenetic study by Oberprieler (2002), on Chamaemelum, using nuclear and plastid DNA markers, suggested that Chamaemelum s.I. is paraphyletic. In Oberprieler's study $C$. fuscatum and $C$. nobile were consistently placed as sister taxa whereas C. mixtum was consistently placed near Cladanthus arabicus (L.) Cass. Consequently, Oberprieler \& Vogt (2002) transferred C. mixtum to Cladanthus, if this placement is accepted, the correct name and authority for this taxon is Cladanthus mixtus (L.) Chevall. 
Achene glands as an aid to identification

Oberprieler (1998) noted that in most species of Anthemideae with ribbed achenes, sessile biseriate glands occur between the ribs. It would appear that these glands occur in young ovaries and are usually lost or degenerate by the time the achene ripens, which would explain why they are rarely recorded in mature achenes. The presence of these glands in the mature achenes is a useful diagnostic feature in herbarium specimens. During our observations on herbarium specimens, spherical yellow glands were observed on the corolla tubes of many of the Mayweeds and Chamomiles, corresponding to those seen by Andreucci et al. (2008) and commonly reported in Asteraceae, e.g. on the corolla tube of Achillea millefolium (Figueiredo \& Pais, 1994).

However, only in $A$. cotula were these droplets easily and frequently found in abundance on the mature achenes (Fig.3d). The presence of these glands in $A$. cotula may be used as an additional diagnostic characteristic to distinguish $A$. cotula from $A$. arvensis, which was never seen to have such oil glands in the mature state in herbarium specimens. Some mature achenes (preserved and fresh) of M. chamomilla also retained similar gland residues (Fig. 6b) though they were more readily observed in immature achenes and were not as immediately obvious as in $A$. cotula. Similar glandular trichomes were also seen in the achenes of $M$. discoidea subsp. discoidea on fresh materials (Fig. 6e). Additionally, similar yellow droplets were observed on some mature achenes of $C$. nobile, particularly in the intercostal furrows of the adaxial face (Fig. 2c). We did not regularly observe them on mature achenes of any other species.

\section{The importance of achene heteromorphy, maturation and colour changes}

Achene colour changes occur both as achenes mature and develop in fresh material and with drying post-collection. Herbarium specimens display a range of achene maturities which can have implications for determination. The achenes of $T$. inodorum and $T$. maritimum, for example, varied from very pale brown to almost black, with the larger achenes generally having the darker colour. In fresh material, those achenes which were immature and green adopted the lighter tan hue within about one month of collection and ambient drying. Similarly, oil sacs varied from bright red to brown to almost black in herbarium specimens, but were green on immature fresh samples, yellowish or brown on more mature achenes and turning red within a few days or weeks of dehiscence. Note that this colour is not due to the oil contained within which is a translucent yellow. The glandular stripes on the achenes of $M$. discoidea were seen to undergo similar colour changes.

The degree of achene maturation may affect how overall length and breadth dimensions are interpreted. This is particularly important when determining specimens of Tripleurospermum which rely on such measurements. The achenes of Tripleurospermum attain most of their length before they increase in width. Thus, the oil sacs were usually clearly elongated in T. maritimum when immature, but that they may also appear elongated in $T$. inodorum until the achenes expand in width (particularly in herbarium specimens in which immature achenes may shrink 
considerably upon loss of water). Thus, it was generally the case that round oil sacs on immature achenes indicated $T$. inodorum quite reliably, but caution was exercised in the case of $T$. maritimum. In the latter case determinations can usually be achieved based on overall habit of the plant, a woody stem if the plant is old enough and leaf characters; though these are also sometimes misleading and the best method of obtaining definitive determination was by obtaining specimens with mature achenes.

The achenes of $A$. arvensis have been described as strongly heteromorphic (Oberprieler, 1998, based on studies of north African populations) and our observations confirm this. The peripheral disc achenes are generally (though not always) more strongly ribbed, sometimes much more so. This could be considered an aspect of maturity: since the lowermost disc florets open first these achenes have longer to develop and by the time the central achenes develop there may be insufficient space in the capitulum for maximal expansion. A similar phenomenon was also observed in $A$. ruthenica, both by us and Bhar \& Mukherjee (2004). On the other hand, such heteromorphy might have an adaptive advantage as the achenes may disperse differently, e.g. those with larger ribs may have better flotation or more or larger mucilaginous cells. To avoid incorrect determinations, it is necessary to consider these various heteromorphies, whether spatial or developmental, when identifying specimens by achene morphology.

\section{Are T. inodorum and T. maritimum distinct species? \\ Stace $(2010,2019)$ comments on the high fertility of T. maritimum $\times$ T.inodorum hybrids ( $80 \%$ or higher, with backcrossing occurring) and the observation that this hybrid is 'not infrequent in coastal areas'. Stace suggests that these observations cast doubt on the distinction of these two species as separate. The authors of the present study have formulated no definite opinion on this, but would comment that the vast majority of specimens could be determined clearly as either T. maritimum or $T$. inodorum on morphological grounds, including achene characters. Only a small minority of specimens 'blurred' the distinction and these are putative hybrids.}

Cline in capitulum size

Kay (1972) reported that northern specimens of T. maritimum in Britain and Ireland have larger achenes. We also observed a similar general trend in capitulum size, with northern specimens of Tripleurospermum having larger and possibly fewer inflorescences per plant. We have also noticed this trend in other British and Irish Asteraceae such as Leucanthemum vulgare and Senecio aquaticus. Whilst these observations are not confirmed by detailed morphometric analysis, there is a distinct possibility that populations of these taxa are experiencing differential ecological pressures along a north-south cline that are analogous to the impacts of altitude.

\section{Conclusions}

It is hoped that the photographs and descriptions provided will assist in the determination of fresh and herbarium specimens of British and Irish mayweeds and 
chamomiles. We propose separating M. discoidea subsp. discoidea and subsp. occidentalis into two separate species since no intermediates were found. We also point out the difficulties in identifying Tripleurospermum hybrids based on achene characters in herbarium specimens, particularly when it is not known if both parents were present in the vicinity.

\section{Acknowledgments}

We would like to thank the following curatorial staff at the Natural History Museum, especially John Hunnex (British \& Irish Herbarium) for his technical and curatorial support as well as Jacek Wajer and Ranee Prakash (General Herbarium) and Fred Rumsey (Senior Curator) for his useful comments on the manuscript. We would also like to thank Chris Raper for technical support and advice on usage of the cameras and Alex Mills and Joe Beale for testing the achene key.

\section{References}

Andreucci, A.C., Ciccarelli, D., Desideri, I. \& Pagni, A.M. 2008. Glandular hairs and secretory ducts of Matricaria chamomilla (Asteraceae): morphology and histochemistry. Annales Botanici Fennici 45: 11-18. Available at: http://www.annbot.net/PDF/anb45-free/anb45-011.pdf

Bhar, I. \& Mukherjee, S.Kr. 2004. Macromorphological and micromorphological study of cypselas in seven species of the tribe Anthemideae (Asteraceae). Journal of Economic and Taxonomic Botany 28: 788-794. Available at: researchgate.net

Bijok, K., Pawlak, T. \& Kreńska, B. 1977. Embryological Studies on Anthemis tinctoria L. Acta Societatis Botanicorum Poloniae 46: 547-557. Available at: researchgate.net

Bremer, K. \& Humphries, C.J. 1993. Generic monograph of the Asteraceae-Anthemideae. Bulletin of the Natural History Museum of London (Bot.) 23: 71-177. Available at: https://www.biodiversitylibrary.org/part/224587\#/summary

Briquet, J., 1916. Études carpologiques sur les genres de composées Anthemis, Ormenis et Santolina. Annuaire du Conservatoire et du Jardin Botaniques de Geneve 18-19: 257-313.

Brouillet, L. 2006a. Matricaria. In: Flora of North America Editorial Committee, eds. $1993+$. Flora of North America North of Mexico. 20+ vols. New York and Oxford. vol. 19, pp. 540-542. Available at: http://www.efloras.org/florataxon.aspx?flora id=1\&taxon id=119860

Brouillet, L. 2006b. Tripleurospermum. In: Flora of North America Editorial Committee, eds. 1993+. Flora of North America North of Mexico. 20+ vols. New York and Oxford. vol. 19, pp. 548-550. Available at: http://www.efloras.org/florataxon.aspx?flora id=1\&taxon id=133732

Clement, E.J. \& Forster, M.C. 1994. Alien Plants of the British Isles. London: Botanical Society of the British Isles.

Figueiredo, A.C. \& Pais, M.S.S. 1994. Ultrastructural aspects of the glandular cells from the secretory trichomes and from the cell suspension cultures of Achillea 
millefolium L. subsp. millefolium. Annals of Botany 74: 179-190. Available at: https://www.jstor.org/stable/42759075?seq=1\#page scan tab contents

Greene, E.L. 1886. Studies in the Botany of California and Parts Adjacent. V(2) Miscellaneous Species, New or Noteworthy. Bulletin of the California Academy of Sciences 2(6): 144-154.

Inceer, H. 2011. Achene slime content in some taxa of Matricaria L. (Asteraceae). Acta Botanica Croatia 70: 109-114. Available at: https://hrcak.srce.hr/66281

Jana, B.K. \& Mukherjee, S. Kr. 2015. Stylopodial diversity of some species of Asteraceae with the help of SEM. Journal of Economic and Taxonomic Botany 39: 138-146. Available at: researchgate.net.

Kay, Q.O.N. 1971a. Biological flora of the British Isles: Anthemis cotula L. Journal of Ecology 59: 623-636. Available at: https://www.jstor.org/stable/2258336?seq=1\#page scan tab contents.

Kay, Q.O.N. 1971b. Biological flora of the British Isles: Anthemis arvensis L. Journal of Ecology 59: 637-648. Available at: https://www.jstor.org/stable/2258337?seq.

Kay, Q.O.N. 1972. Variation in sea mayweed (Tripleurospermum maritimum (L.)Koch) in the British Isles. Watsonia 9: 81-107. Available at: http://archive.bsbi.org.uk/Wats9p81.pdf.

Kay, Q.O.N. 1994. Biological flora of the British Isles: Tripleurospermum inodorum (L.) Schultz Bip. Journal of Ecology 82: 681-697.

Lo Presti, R.M., Oppolzer, S. \& Oberprieler, C. 2010. A molecular phylogeny and a revised classification of the Mediterranean genus Anthemis s.l. (Compositae, Anthemideae) based on three molecular markers and micromorphological characters. Taxon 59: 1441-1456. Available at: https://www.jstor.org/stable/20774040?seq=1\#page scan tab contents.

Oberprieler, C. 1998. The Systematics of Anthemis L. (Compositae, Anthemideae) in W. and C. North Africa. Bocconea 9: 1-328.

Oberprieler, C. 2002. A phylogenetic analysis of Chamaemelum Mill. (Compositae: Anthemideae) and related genera based upon nrDNA ITS and cPDNA trnL/trnF IGS sequence variation. Botanical Journal of the Linnean Society 138: 255-273. Available at: Oxford Academic.

Oberprieler, C. \& Vogt, R. 2002. Cladanthus Cass. In: Greuter W. \& Raus T. (eds.), MedChecklist Notulae, 21. Willdenowia 32: 195-208. Available at: https://www.bgbm.org/sites/default/files/documents/w32-2MedCheck-21.pdf.

Pliszko, A. \& Heise, W. 2016. Lectotypification of X Anthepleurospermum gruetterianum (Asteraceae). Acta Mus. Siles. Sci. Natur., 65: 101-103. Available at: https://core.ac.uk/download/pdf/53138623.pdf (and at ResearchGate).

Quaiser, M. 2006. Tripleurospermum. In: Flora of Pakistan Editorial Committee, eds. 1993+. Flora of Pakistan. 20+ vols. New York and Oxford. vol. 207, pp. 33-35. Available at: http://www.efloras.org/florataxon.aspx?flora id=5\&taxon id=133732.

Sell, P. \& Murrell, G. 2006. Flora of Great Britain and Ireland.Vol. 4. Cambridge: Cambridge University Press. 
Stace, C.A. 2010. New Flora of the British Isles. 3rd. ed. Cambridge: Cambridge University Press.

Stace, C.A. 2019. New Flora of the British Isles. 4th. ed. Stowmarket: C. \& M. Floristics.

Stace, C.A., Preston, C. D. \& Pearman, D. A. 2015. Hybrid Flora of the British Isles. London: Botanical Society of Britain and Ireland.

Syme, J.T.B. ed. 1866. English Botany 5: 52. Available at: https://www.biodiversitylibrary.org/item/101468\#page/61/mode/1up.

Tison, J. \& Foucault, B. 2014. Flora Gallica: Flore de France. Biotope Editions and The Botanical Society of France.

Tutin, T.G., Heywood, V.H., Burges, N.A., Valentine, D.H., Walters, S.M. \& Webb, D.A. eds. 1976. Flora Europaea. Cambridge: Cambridge University Press.

Verloove F. 2012a. Anthemis and Anthemis ruthenica. On: Manual of the Alien Plants of Belgium. Botanic Garden of Meise, Belgium. At: alienplantsbelgium.be, accessed 25/01/2018. Available at: http://alienplantsbelgium.be/content/anthemisruthenica.

Verloove F. 2012b. Cota. On: Manual of the Alien Plants of Belgium. Botanic Garden of Meise, Belgium. At: alienplantsbelgium.be, accessed 25/01/2018. Available at: http://alienplantsbelgium.be/content/cota.

Verloove F. 2015. Tripleurospermum decipiens. On: Manual of the Alien Plants of Belgium. Botanic Garden of Meise, Belgium. At: alienplantsbelgium.be, accessed 25/01/2018. Available at: http://alienplantsbelgium.be/content/tripleurospermum-decipiens.

Yang, X., W. Zhang, M. Dong, I. Boubriak \& Z. Huang, 2011. The Achene Mucilage Hydrated in Desert Dew Assists Seed Cells in Maintaining DNA Integrity: Adaptive Strategy of Desert Plant Artemisia sphaerocephala. PLOS ONE [online] 6 (September 2011) [accessed 28 September 2017]. Available at: http://journals.plos.org/plosone/article?id=10.1371/journal.pone.0024346.

ISSN: $2632-4970$

https://doi.org/10.33928/bib.2019.01.128 